\title{
Functionally Graded Ceramics for biomedical application: concept, manufacturing, properties
}

\author{
Clémence Petit, Laura Montanaro, Paola Palmero*
}

\begin{abstract}
Department of Applied Science and Technology and INSTM Research Unit PoliTO, LINCE
Laboratory, Politecnico di Torino, Corso Duca degli Abruzzi, 24, Italy;
\end{abstract}

*Corresponding author: paola.palmero@ polito.it, phone no. +39 (0)11 0904678; fax no. +39 (0)11 0904624

\begin{abstract}
Functionally Graded Materials (FGMs) represent a novel approach for the realization of innovative properties and/or functions that conventional homogeneous materials cannot accomplish. In conventional materials, in fact, the composition or the structure is uniform over the volume; on the opposite, in FGMs such features gradually change from layer to layer, with the aim of realizing a gradation of properties over the volume and performing a set of specified functions.

Among FGMs, special attention is given today to Functionally Graded Ceramics (FGCs), designed and developed to withstand a variety of severe operative conditions, including high temperatures, corrosive environments, abrasion, mechanical and thermal induced stresses. An important application field of FGCs is for medical prosthetic devices and artificial tissues, taking inspiration from the several examples of living tissues with graded structures. After an introduction on the rationale for using FGCs in the biomedical field, the three main types of graded materials developed today (e.g., composition, porosity and microstructural graded ceramics) are here reviewed, highlighting the most innovative technologies used to develop them, their potentials and challenging features in comparison with the monolithic counterparts.
\end{abstract}

\section{Keywords}

Functionally graded ceramics (FGCs); biomedical applications; dental ceramics; interface tissue engineering; graded scaffolds

\section{Introduction to FGCs}

Functionally Graded Materials (FGMs) represent a novel approach for the realization of innovative properties and/or functions that conventional homogeneous materials cannot accomplish. In 
conventional materials, in fact, the composition or the structure tends to be uniform over the volume; on the opposite, in FGMs such features gradually change from layer to layer, giving rise to gradual variations in the macroscopic properties.

Different examples of FGMs are available in literature [1, 2, 3, 4, 5], showing gradation in composition, micro/nanostructure (grain size, grain shape, texturization level, etc.), density and other physico-chemical properties. Two main key features characterize FGMs: on the one hand, the spatially varying property is designed to optimize a desired performance across the whole volume; on the other hand, the sharp interfaces existing in traditional composite materials - which is the location where failure is often initiated, are here eliminated. For these reasons, FGMs are reported to exhibit superior mechanical properties when compared to basic (monolithic) and composite structures [2].

The first example of FGMs with industrial application was developed in the 1960's: Fitzer et al. fabricated a structure based on carbon and silicon carbide for nuclear fuel ball [6]. Schlichting et al. developed $\mathrm{Mo} / \mathrm{MoSi}_{2}$ graded structures for Wankel engine sealing blades [7]. At the end of the 1980 's, a new graded thermal barrier coating was proposed in Japan by Niino and co-workers, in the frame of the research project titled "Fundamental Studies on the Relaxation of Thermal Stress by Tailoring Graded Structures" [8]. Due to the challenging requirements (a thermal barrier material able to withstand a surface temperature of $2000 \mathrm{~K}$ and a temperature gradient of $1000 \mathrm{~K}$, in a cross-section of less than $10 \mathrm{~mm}$ ), the FGM concept was exploited to manufacture the body of a space plane, using a ceramic material for the outer surface that is exposed to high temperatures and a thermally conductive metal for the inner surface [2]. In such a way, both refractoriness and mechanical properties were satisfied in an innovative layered material.

Since a single material was not able to withstand both high refractoriness and mechanical properties, an innovative layered component was designed, made by an outer ceramic layer to withstand high temperatures and a thermally conductive material for the inner one surface.

In the past, the compositions of FGMs typically included at least one metallic phase. More recently, the attention focused on ceramic-ceramic and glass-ceramic systems, due to their enormous potential. Functionally Graded Ceramics (FGCs) are designed to withstand a variety of severe operative conditions, including high temperatures, corrosive environments, abrasion, mechanical and thermal induced stresses [2]. An overview of the FGC structures already [9-56] developed and their main application fields is proposed in Table 1.

Although FGCs were developed fairly recently, these materials are not actually new. Gradual variations in the microstructure of materials have been exploited for millions of years by the living 
organisms. FGMs have been long established in nature (biotissues of plants, bamboos, shells, coconut leaves and animals) and are even found in our bodies - such as in bones and teeth [57].

In this work, special attention will be given to FGCs for application in the biomedical field. Rationale and potentials of FGCs for use in medicine are illustrated in the next paragraph. In the following ones, a deepening of the three main typologies of FGCs which are developed today (e.g., composition, porosity and microstructural graded ceramics) is proposed, highlighting the most innovative technologies used to develop them, when possible. In particular way, the most recent advances achieved by ceramic-ceramic and ceramic-glass functionally graded systems are analysed, also including fewer but representative examples of ceramic-polymer multi-layer structures. As a choice, ceramic-metal systems are not here discussed, as several and exhaustive works on their application in medicine are already available in literature $[3,58]$ and some implants already commercially used [59].

\section{Rationale for the use of FGCs in the biomedical field}

Multi-layered and graded materials play a substantial role in the human body. For instance, human skin is a complex multi-layered system, consisting of the epidermis, dermis and underlying hypodermis, each layer having distinct mechanical properties [60].

Other examples of graded systems in the human body are provided by the so-called "interface tissues", located between different tissue types, such as tendon-to-bone and cartilage-to-bone junctions [61].

The tendon-to-bone insertion, for instance, is a ligament that connects two extremely different tissues across a millimetre-wide region: on one side, the soft tissue of the tendon and on the other side, the hard and stiff tissue of bone. Genin et al. observed that the tendon-to-bone insertion is able to withstand such a difference in mechanical behavior thanks to the concomitant action of a compositional gradient and a structural one [62].

A further example of multilayer structure is provided by the osteochondral junction. This zone can be divided into four layers (superficial, middle, deep and calcified cartilage) depending on their different characteristics, including cell types, matrix composition, collagen fibre orientation and mechanical properties. The superficial zone is the thinner layer, composed of flattened chondrocytes with their long axes parallel to the articular surface. It has highest collagen content, with densely packed collagen fibrils, highly ordered and parallel to the articular surface [63]. Functionally, it provides a smooth gliding surface, with the lowest compressive modulus and high deformability [63]. The intermediate middle zone encompasses $40 \%$ to $60 \%$ of the articular cartilage volume. Characterized by a less organized arrangement of the collagen fibres [64, 65, 66], it is regarded as a 
zone in which the structure and components are transitional between the superficial and deep layers [63]. The deep zone, with the highest compressive modulus, is characterized by radially organized components [63]; finally, the calcified zone or "subchondral bone" is where the transition from soft to stiff subchondral bone occurs, responsible for firmly attaching the non-calcified cartilage to the underlying subchondral bone [67]. The first three layers consist of mostly collagen type II (90\%), glycosaminoglycans, cells and water; the last layer consists of collagen type I and type X, osteocalcin and hydroxyapatite. The cellular content of this junction shows a transition from chondrocytes in the superficial layers to osteoblasts and osteoclasts in the subchondral bone, with some overlap in function and characteristics $[67,68]$.

As a further example, the bone itself could be regarded as a functionally graded system [69]. By the compositional point of view, the bone tissue is mainly made by mineralized extracellular matrix (ECM), containing both organic and inorganic phases: type-I collagen and hydroxyapatite, $\mathrm{Ca}_{10}\left(\mathrm{PO}_{4}\right)_{6}(\mathrm{OH})_{2}$. By the structural point of view, bones can be classified in various groups, but all of them present complicated, hierarchical structures. A typical example is given by long bones, which consist of a basic dual structure. The external layer, named cortical bone, is smooth, continuous and dense (approximately $1.85 \mathrm{~g} / \mathrm{cm}^{3}$ ). The interior (cancellous bone) is porous with a honeycomb structure, filled with blood vessels and bone marrow, with an average porosity of $75-95 \%$ and an average density of $0.3 \mathrm{~g} / \mathrm{cm}^{3}$ [70]. When observed across its transverse section, human bone shows a graded structure varying its pore size and porosity distribution, as shown in Figure 1 (A) [69]. The size of the pores in normal bone are predominantly in the range of 1-100 microns [71]. Only the smaller canaliculi and vasculature channels [71] are in the 1-5 micron range. Osteocyte lacunae and Volksmann's canals are typically 5-15 microns in diameter, while the larger Haversian canals are 50100 microns in diameter $[71,72]$.

Thus, bone displays a change from a dense external stiff structure to a porous internal one. This configuration corresponds to an optimized mechanical design, which produces uniform stress distribution with no localized stress peaks [1]. The typical mechanical properties of cortical and cancellous bone are shown in Table 2. The anisotropic structure of cortical bone accounts for the different properties determined under longitudinal $(\mathrm{L})$ or transversal $(\mathrm{T})$ directions of the applied load [70, 73-79]. In spite of such difference, a gradual decrease in mechanical properties - moving from cortical to cancellous bone, can be easily observed.

A last example of natural graded structures is provided by teeth, with a unique hierarchical architecture that is responsible of the extraordinary mechanical properties required during the mastication process [80-84]. The structural parts of a human tooth consists in enamel, dentin and dentin-enamel junction (DEJ), as shown in Figure 1 (B). Enamel forms the outer layer of the tooth 
and it is mainly composed by apatite crystals in the form of large rods ( $\sim 5 \mu \mathrm{m}$ in diameter), oriented in a perpendicular direction from the DEJ toward the tooth surface. They are held together by a minor (1-2 wt\%) organic phase, composed by a protein/peptide mixture. Enamel must resist to high contact stress (of about $2.5 \mathrm{GPa}$ ), due to direct contact with opposite teeth and external objects [85]. Therefore, high hardness, stiffness and sufficient toughness are essential to support high stress and minimize cracking and fracture. Regarding the dentin, it consists of dentinal tubules (65-70 wt\%) wrapped with peritubular dentin and embedded in a collagen matrix containing hydroxyapatite prisms. As a result of this dual structure, the surface of the teeth (enamel) is hard and brittle and extremely wear resistant, whereas the internal part (dentin) is softer, flexible and durable. The main mechanical properties of these two layers are summarized in Table 2. Between them, a functionally graded junction (DEJ) is present allowing a smooth transition of the mechanical properties: hardness decreases from the outside enamel region towards the dentin, while toughness increases. Such an interface inhibits the propagation of cracks from the enamel to the dentin, thus supporting the tooth integrity during masticatory actions.

Inspired by those examples of natural tissues, the development of artificial implants with graded structures and functionalities is nowadays increasing [86]. Table 3 gives an overview of different FGCs developed in the biomedical field with their main applications [46-48, 51, 87-112].

With reference to scaffolds for bone regeneration, the amount and size distribution of porosity - both at macroscopic and microscopic level, are important morphological properties. Although the bone ingrowth mechanisms depend on the biomaterial itself, it is commonly recognized that relatively larger pores favour direct osteogenesis (through vascularization and high oxygenation) and osteointegration, while smaller pores result in osteochondral ossification [70].

Henriques [1] reported that the fabrication of hydroxyapatite ceramics with porosity gradients improved the osteoconduction and demonstrated excellent bioactivity.

In addition, by modulating the density from layer to layer, a better mimicking of the natural bone is achieved, with the result of coupling the necessary mechanical strength to biological functions. A common approach is to develop a graded structure, but inverse as compared to natural bone, with a dense core and a porous surface [46]. In fact, the macropores in the outer layer provide access for cells and blood vessels and enhance the formation of new bone, whereas the inner denser structure improve the strength of the implant [113].

Tuning or grading the porosity is even more important in the case of multiple tissues regeneration, as in the case of bone-to-cartilage junction. Here, more than one cell type is necessary, and these different cells require different environments in vivo. This means that they have different scaffold requirements, mainly in terms of pore sizes and amount [114]. Thus, a well-engineered scaffold 
should be tailored with the appropriate pore features according to the needs of the specific cells, in order to better accommodate the proliferation and growth of the cells [70, 114]. Previous studies [115, 116] have demonstrated that the pore size and substrate surface morphology influence cell morphology and phenotypic expression. This means that different sizes of pores are suitable for ingrowth of different tissues [117]. This aspect has been investigated by several researchers, correlating the cell types to their preferred scaffold pore size, as reported in Table 4 [114].

Therefore, while uniform porous materials only allow one particular tissue type to grow in, graded porous materials can repair and reconstruct two or more different tissues simultaneously, as the different regions provide different microenvironments.

The concept of functionally graded structures has been also applied to dental restorations, showing improvement in damage resistance and aesthetic appearance as compared to tradition materials.

In fact, the unsatisfactory performance reported by clinical studies on all-ceramic restorations, such as fracture, poor aesthetic properties of ceramic cores, as well as the difficulty in achieving strong ceramic-resin-based cement bond have been successfully addressed by the FGC systems [1]. To fully understand the advantages provided by FGCs, we should consider that traditional dental restorations are usually made by a strong framework, responsible for withstanding masticatory stresses, and a veneer layer responsible for aesthetics. $\mathrm{ZrO}_{2}$ and $\mathrm{Al}_{2} \mathrm{O}_{3}$ have been used as framework materials due to their excellent mechanical properties, good aesthetic and biocompatibility [124-126]. Porcelain is the material chosen as veneer, due to its colour and translucency appearance that matches the ones of the teeth. In the processing of all-ceramic restorations, porcelain is fired onto the framework at high temperatures; during subsequent cooling, thermal residual stresses - due to differences in the coefficients of thermal expansion (CTEs) between the framework and the veneering porcelain, arise at their interface $[127,128]$. In addition, the mismatch between the Young's moduli of the two ceramic phases creates stress fields upon mastication, which can lead to crack formation, porcelain chipping and ultimately catastrophic failure of the prosthesis [128, 129]. A solution to overcome this problem is using an interlayer with intermediate properties between the framework and the veneer, allowing reducing the mismatches in materials properties. Recent studies have shown that gradation of properties across the two materials is an excellent approach to mitigate residual stresses and improve the performance of dental restorations $[55,56,91,130]$.

Still with the aim of overcoming the high failure rate occurring at the core-veneer interface [129], it does exist a second way to exploit the FGCs concept. It consists in the infiltration of the $\mathrm{Al}_{2} \mathrm{O}_{3}-$ or $\mathrm{ZrO}_{2}$-core with a glass, producing a gradation in composition, microstructure and properties [90, 131,132]. Within this approach, the application of the external veneer can be avoided. On the opposite, it is possible to fabricate dual-phase single pieces, in which the residual outer glass layer 
provides the required aesthetic appearance, followed by a graded ceramic-glass structure characterized by a progressive increase in density, elastic modulus and hardness [55, 90, 131, 132].

\section{Compositional graded ceramics for biomedical applications}

\subsection{Bioinert and bioactive ceramics}

Different types of ceramic materials are used for biomedical applications. Generally, it is possible to distinguish bioceramics into bioinert, bioactive and bioresorbable [133,134].

Bioinert ceramics, such as $\mathrm{Al}_{2} \mathrm{O}_{3}$ and Yttria-Stabilized $\mathrm{ZrO}_{2}$ (hereafter labelled as Y-TZP), are characterized by high strength, hardness and wear resistance, but they are nearly inert, meaning that they show a negligible interaction with the surrounding living tissues [135,136]. They are mainly used for high load-bearing applications, such as hip prostheses for orthopaedics and dental implants and restorations [137]. Bioactive ceramics, on the opposite, can play an active role in biological processes. Bioactivity, for example, consists of supplying constitutive building blocks (e.g., ions) for inducing chemical bonding with living tissue, promoting tissue regeneration or activating biological pathways (e.g., favouring or orienting cell activity). Finally, bioresorbable ceramics show the unique property to be resorbed in vivo, thus to be replaced by natural bone in the bone tissue. Among bioactive and bioresorbable ceramics, calcium phosphates $(\mathrm{CaP})$ are widely used for bone substitution $[133,138]$. Hydroxyapatite $\left(\mathrm{HA}, \mathrm{Ca}_{10}\left(\mathrm{PO}_{4}\right)_{6}(\mathrm{OH})_{2}\right)$ and $\beta$-tricalcium phosphate $\left(\beta\right.$-TCP, $\left.\mathrm{Ca}_{3}(\mathrm{PO} 4)_{2}\right)$ are the most used $\mathrm{CaP}$ phases due to their chemical compositions close to the mineral part of bone [139]. They are biocompatible [140] and osteoconductive [141,142]. HA is known to be more efficient to bond directly with bone [143], whereas $\beta$-TCP shows a higher bioresorbability in vivo [144]. Biphasic Calcium Phosphate (BCP) materials consist in a mixture of HA and $\beta$-TCP [145]. The association of the two CaP phases allows a control of the dissolution rate thanks to the HA/ $\beta$ TCP rate: the lower the rate, the higher the resorbability $[145,146]$. BCP can be fabricated by mechanical mixing of commercial HA and $\beta$-TCP powders [147] or by sintering of a calcium deficient apatite $\left(\mathrm{CDA}, \mathrm{Ca}_{10-\mathrm{x}}\left(\mathrm{HPO}_{4}\right)_{\mathrm{x}}\left(\mathrm{PO}_{4}\right)_{6-\mathrm{x}}(\mathrm{OH})_{2-\mathrm{x}}\right)$ [148]. This latter phase decomposes into $\mathrm{HA}$ and $\beta$ TCP above $700^{\circ} \mathrm{C}$ and the $\mathrm{Ca} / \mathrm{P}$ ratio of the sintered sample reflects the $\mathrm{Ca} / \mathrm{P}$ ratio of the initial CDA $[148,149]$. Due to their low mechanical properties (for HA, fracture strength range of 90-120 MPa [150] and fracture toughness range of 1.0-1.2 $\mathrm{MPa} \vee \mathrm{m}$ [151]) in comparison with those of human bone (see values in Table 2), their applications are limited to low load-bearing functions or small segmental bone defects [141,142]. HA is a stoichiometric component whereas the mineral part of bone is composed of a biological apatite. The latter is characterized by many possible cationic $\left(\mathrm{Ca}^{2+}\right.$ sites) or anionic $\left(\mathrm{PO}_{4}{ }^{3-}\right.$ and/or $\mathrm{OH}^{-}$sites) substitutions [152]. The predominant substituent in the 
mineral part of bone is the carbonate ion $\left(\mathrm{CO}_{3}{ }^{2-}\right)$ [153]. It is known to reduce the crystallinity in the apatite lattice, thus to increase its solubility and to enhance bone regeneration [152,154]. Carbonate can substitute to the two anionic sites of the $\mathrm{HA}$ structure: at $\mathrm{OH}^{-}$sites (A-type substitution) and at $\mathrm{PO}_{4}{ }^{3-}$ sites (B-type substitution) [153-156]. The presence of both types of substitutions has been reported [157]. For this reason, many authors synthesized substituted apatites and especially carbonate apatites $[155,158,159]$ to obtain bone substitution closer to the mineral part of bone.

Bioactive glasses are another class of bioactive materials mainly used for bone substitution. The first bioactive glass was named $45 \mathrm{~S} 5$ or Bioglass ${ }^{\circledR}$ : it was a silicate glass containing $\mathrm{Na}_{2} \mathrm{O}, \mathrm{CaO}$ and $\mathrm{P}_{2} \mathrm{O}_{5}$ (with a high $\mathrm{Ca} / \mathrm{P}$ ratio) [160]. It was discovered that this glass was able to bond strongly and quickly with bone via the formation of a carbonate-substituted apatite layer on the glass surface [161-163]. Since then, many other materials were developed: bioactive glasses with other compositions (borate or borosilicate based glasses [163, 164]) or glass-ceramics [165].

\subsection{FGCs made from bioinert and/or bioactive ceramics}

Different bioinert (resp. bioactive) ceramics can be associated to obtain a gradation in composition, in order to take advantage of the difference in properties of the constituent materials. However, different approaches have been followed.

The first one relates to graded ceramics based on the combination of all-inert phases, to maximize the mechanical performances. Anné et al. realized complex-shape functionally graded $\mathrm{Al}_{2} \mathrm{O}_{3} / 3 \mathrm{Y}$-TZPbased femoral heads [48]. The composition gradient was engineered to obtain a pure $\mathrm{Al}_{2} \mathrm{O}_{3}$ surface region and a homogeneous $\mathrm{Al}_{2} \mathrm{O}_{3} / \mathrm{ZrO}_{2}$ core, with intermediate continuously graded regions. The final goal was to generate appropriate and controlled thermal residual stresses after sintering, and particularly a compressive surface in the outer $\mathrm{Al}_{2} \mathrm{O}_{3}$ layer, with beneficial effect on the wear resistance [87]. To achieve the designed graded complex structure, the electrophoretic deposition (EPD) technique was employed, in which the composition of the ceramic suspension was opportunely adjusted during deposition time. In a similar research [88], sequential slip-casting of $\mathrm{Al}_{2} \mathrm{O}_{3}$ and $\mathrm{ZrO}_{2}$ aqueous suspensions was used to develop the same compositionally graded material. X-ray diffraction and neutron diffraction analysis confirmed the presence of a residual compressive stress at the surface of the step-graded samples. Both wear and friction decreased with an increase in the compressive stress level, as predicted, leading to a reduction of crack nucleation and propagation phenomena. As a point of innovation, Ginter at el. showed the potential of the direct inkjet printing (DIP) technology in producing $\mathrm{Al}_{2} \mathrm{O}_{3} / 3 \mathrm{Y}-\mathrm{TZP}$ [49] innovative structures. 3D ceramics and FGCs are built up via precise drop-wise combination of materials on the substrate, by implementing different printheads for $\mathrm{Al}_{2} \mathrm{O}_{3}$ and 3 Y-TZP. Cylindrical parts consisting of 800 single layers were produced, with a sintered density 
of $97.5 \%$. No delamination or other process-related flaws were observed. Further improvement of the DIP technology will permit the creation of graded structures with varying material composition in every spatial directions.

The second approach relates to FGCs made by all-active bioceramics (mainly CaP or bioglass) with the aim of modulating the biological properties, especially about the bioresorbability. Kon et al. [100] fabricated a FGC structure, with a gradation of HA and $\alpha$-TCP weight fraction. $\alpha$-TCP is a hightemperature polymorph of $\beta$-TCP which can be retained at room temperature and is characterized higher solubility than HA and $\beta$-TCP [166]. Wong et al. [101] developed a dense four-layer FGC based on fluorine-substituted apatite and $\beta$-TCP with a variation of $\beta$-TCP content from one layer to the other. Marković et al. developed FGCs based on CPs, realizing a simultaneous gradation in density, phase composition (HA/ $\beta$-TCP ratio) and mechanical properties (hardness and Young's modulus). Multilayered samples were fabricated by uniaxial pressing of stoichiometric HA and calcium deficient HA powders. During reaction sintering, calcium deficient HA transformed in BCP $(\mathrm{HA}+\beta-\mathrm{TCP})$, finally yielding HA/BCP FGMs, which could provide appropriate resorption rate of artificial bone material [167].

Finally, the third and most exploited approach implies the joining of bioinert with bioactive ceramics, to obtain new combination of properties. In particular, for orthopaedic applications, bioinert and bioactive ceramics are combined to provide an ideal combination of bioactivity, mainly localized at the material surface, with suitable physical and mechanical properties of the bulk.

The first solution developed to achieve this combination of properties was realized by coating $\mathrm{Al}_{2} \mathrm{O}_{3}$ or $\mathrm{ZrO}_{2}$ implants by active ceramics (such as HA [103] or bioactive glass [104]). Coating is a wellknown process used to modify the surface properties without altering the bulk. In the biomedical field, the idea of modifying the implant surface is based on the fact that surface properties greatly affect the biological behaviour of a biomaterial [168,169] and could promote tissue integration and ingrowth. The most common processes to apply coatings include dip coating [105], plasma spraying [170] and sputtering [171]. Although the wide literature related to the application of coatings on biomedical materials and devices, some issues still remain, especially for CaP coatings. Poor stability of the coated layer and weak bond strength have been often observed [169], which could lead to delamination and failure [172]. Moreover, in the case of CaP-coated $\mathrm{ZrO}_{2}$ or $\mathrm{Al}_{2} \mathrm{O}_{3}$, reactions between the different phases can occur and generate undesirable new phases at the interfaces (e.g. $\mathrm{CaZrO}_{3}$ from $\mathrm{ZrO}_{2}$ and $\mathrm{HA}$ [173] or $\mathrm{CaAl}_{2} \mathrm{O}_{4}$ from $\mathrm{HA}$ and $\mathrm{Al}_{2} \mathrm{O}_{3}$ [174]). To overcome these problems, one approach consists in creating a gradient of composition in the coated layer itself, giving rise to multilayered coatings. Following this approach, Kim et al. [105] added an intermediate layer of fluorapatite between zirconia and HA layers. Shahabudin et al. [175] fabricated a HA coated alumina 
foam by dip coating with a bentonite intermediate layer. It was shown that the HA layer was more uniform on the alumina struts in the presence of the bentonite intermediate layer. Various glass/HA layers were coated on a titanium substrate with a gradient in HA content from the inner layer (0 wt $\%)$ to the outer layer (100 wt\%) [176].

Compositionally FGCs appear as a good alternative to both single- and multi-layer coatings, in which the gradation is realized within the bulk of the materials, and not only at the surface, without distinction between a substrate and a layer. In order to combine mechanical performance to biological activities, Afzal et al. developed an $\mathrm{HA}-\mathrm{Al}_{2} \mathrm{O}_{3}$-Yttria-stabilized tetragonal $\mathrm{ZrO}_{2}(\mathrm{Y}-\mathrm{TZP})$ structure, characterized by a smooth gradation of functionalities: enhanced toughening of the Y-TZP bulk, and retained biocompatibility of the HA surface [51]. Due to the significant difference in fracture toughness of $\mathrm{HA}(\sim 1.2 \mathrm{MPa} \sqrt{\mathrm{m}}[129])$ and Y-TZP $(\sim 9 \mathrm{MPa} \sqrt{\mathrm{m}}[130])$, these two materials have been joined by a transition layer of $\mathrm{Al}_{2} \mathrm{O}_{3}$ (having an intermediate fracture toughness of $\sim$ 4-5 MPa $\sqrt{\mathrm{m}}$ [177]), allowing a minimum gradient of mechanical properties. More in details, three layers of powders (the former made by $\mathrm{HA}+20 \mathrm{wt} \% \mathrm{Al}_{2} \mathrm{O}_{3}$, the intermediate by $\mathrm{Al}_{2} \mathrm{O}_{3}+20 \mathrm{wt} \% \mathrm{Y}-\mathrm{TZP}$ and the latter by pure Y-TZP) were sintered together by Spark Plasma Sintering (SPS) process. The stepwise functional variation of hardness and toughness along the cross section of graded material was successfully achieved. Strong adherence and absence of cracking at the interfaces indicated matching of fracture toughness gradation. Successive cell culture experiments provided clear evidences of cell adhesion and cell proliferation on the HA surface, indicating good cytocompatibility of the material. These results suggest the potential use of this new graded structure as bone replacement material in demanding orthopaedic applications, which require good biocompatible surface besides better toughness and hardness.

Guo et al. produced a laminated and functionally graded HA/Y-TZP ceramic, still by SPS [53]. In this case, powder mixtures of HA and Y-TZP (containing 0, 10, 20, 30 and $40 \mathrm{wt} \%$ Y-TZP) were ball-milled and uniaxially pressed, before sintering at $1200^{\circ} \mathrm{C}$. The Y-TZP grains were uniformly dispersed in the HA matrix, the latter showing a significant lower grain size as compared to that in pure HA phase. Most important, HA/Y-TZP functionally graded composites showed remarkable improvement in mechanical property compared with pure HA ceramics. The microhardness and Young's modulus increased stepwise from the pure HA layer to the HA+40 wt\% Y-TZP layer across the functionally graded composite. The bending strength of the graded material reached around 200 $\mathrm{MPa}$, which was almost the double of the strength achieved by pure HA ceramics.

Several works relate to the development of glass/alumina or zirconia graded structures, especially for dental applications [90, 91,131]. In fact, ceramic dental crown restorations are normally used to replace the damaged tooth structure. In this field, high-strength ceramics, like $\mathrm{Al}_{2} \mathrm{O}_{3}$ and $\mathrm{ZrO}_{2}$, are 
normally used. However, an important issue is their quite opaque appearance, needing an outer thick porcelain veneer, able to induce a gradual change in translucency to mask the ceramic core and to achieve a better aesthetic outcome. Therefore, new FGCs materials have been successfully designed and developed to combine an aesthetic, low elastic modulus and low hardness glass veneer with a high strength ceramic core, without a sharp interface between the materials. Fabris et al. compared the thermal residual stresses generated inside "traditional" ceramic restorations, made by a strong ceramic framework and an external aesthetic veneer with those of multi-layer ceramics [178]. In particular way, three different multi-layer designs were analysed by finite elemental analysis: $i$ ) a conventional two-layer (zirconia core - feldspathic porcelain veneer); ii) a three-layer structure, with a step-wise transition from the bottom zirconia layer to the upper porcelain one; $i i i$ ) a graded structure, with a continuous transition between the two layers. It was shown that both homogeneous and graded multi-layer structures (e.g, ii) and iii)), yielded the lowest thermal stress, significantly lower as compared to the two-layer system. These results indicate that, by proper design, it is possible to reduce the risk of failure for all-ceramic dental materials and to develop more reliable restorative systems. Zhang et al. developed functionally graded structures to fabricate all-ceramic restorations with proper aesthetics [90, 132]. Two kinds of ceramic-glass graded structures were prepared, based on $\mathrm{Al}_{2} \mathrm{O}_{3}$ and 3Y-TZP, respectively. Two silicate glasses were developed to infiltrate the two ceramic substrates, by tuning the compositions in order to match as much as possible the CTE of the ceramic cores and to avoid significant residual thermal stresses. In such a way, only a gradation of the elastic modulus was produced in the two materials. The high glass content present at the surface of both $\mathrm{Al}_{2} \mathrm{O}_{3}$ and 3 Y-TZP-based FGCs provided the required optical appearance of the material and was characterized by an elastic modulus of $\sim 67 \mathrm{GPa}$, similar to that of dental porcelain. Then, the glass concentration gradually decreases moving towards the inner layers, leading to a dense Y-TZP as well as $\mathrm{Al}_{2} \mathrm{O}_{3}$ core. In the case of $\mathrm{ZrO}_{2}$-glass system, the glassy phase induced a significant growth of the zirconia grains, which however maintained their tetragonal structure and hence their toughening effect. In both materials, a gradual increase of the elastic modulus - moving from the surface to the core - was achieved as well as superior load-bearing capacity, 20-50\% higher than conventional homogeneous materials. In Figure 2, an image of $\mathrm{ZrO}_{2}$-based graded dental units, with a thin external aesthetic glass layer at both the occlusal and cementation surfaces, is depicted [132].

Still in the frame of ceramic dental restorations, GFCs are also exploited to overcome the second important issue related to their high failure rate (around 1-3\% each year [179]). The major clinical failure mode is the subsurface radial crack in the ceramic, induced by the tensile stress concentration at the interface between the crown (e.g., the dental ceramic) and the cement [86], which plays the role to join the crown to dentin. This phenomenon is mainly due to the Young's modulus mismatch 
between the ceramic crown material and the cement, as already reported in section 2 . On the other hand, in natural tooth, the DEJ provides a graded interface between dentin and enamel layers, thus reducing the stress in the surrounding parts [180]. Therefore, inspired by the structure of the DEJ, many efforts today are focusing on the development of FGCs layers, to be placed between the ceramic core and the dental cement, with the aim to grade the stiffness from the exterior to the inner part. Finite element simulations [86, 91, 181] show that the presence of a FGM layer can significantly reduce the interfacial stress (up to 30\%) and increase the critical crack length [86] with the result of improved durability of the ceramic prosthesis.

\subsection{FGCs made from ceramic-polymer composites}

To conclude this section, ceramic-polymer graded materials for tissue engineered scaffolds have to be mentioned. In particular way, this concept applies to osteochondral defects, which encompass injury in bone, cartilage and bone-cartilage interface. With a better understanding of the mechanical performance, structure and biology of bone and cartilage, the reconstruction of these two individual areas has led to improved tissue engineering constructs. However, real advances have been achieved only after a deeper understanding of osteochondral interface and bone-cartilage interactions [182]. This has led to multiphasic or graded scaffolds, in which two materials are used, one to resemble the cartilage, the other the subchondral bone/bone phase. In addition, a structural interface is also added, to mimic the transitional area between these two parts [183].

Tampieri et al. developed HA/collagen-based osteochondral scaffolds, organized in different integrated layers [110]. In particular way, the structure was composed by a lower layer made by mineralized collagen (HA/collagen: 70/30 wt\%) mimicking the subchondral bone; an intermediate layer, with a lower content of mineral phase (HA/collagen: 40/60 wt\%) and resembling the tidemark; an upper layer, made by hyaluronic acid-charged collagen, mimicking the cartilaginous region. The layers were stacked and freeze-dried to obtain an integrated monolithic composite. The different layers were expected to induce, selectively, bone or cartilage tissues ingrowth. In fact, the material loaded with articular chondrocytes and cultured for 2 weeks yielded cartilaginous tissue formation exclusively in the upper layer; on the opposite, in the subchondral layer, only a fibrous tissue was developed. On the other hand, etopic implantation in nude mice of the graded scaffold, after loading with bone marrow stromal cells, resulted in new bone formation, which remained confined within the lower mineralized layer, and was not present in the cartilaginous region.

Jiang et al. developed a multiphase osteochondral scaffold, having the following composition: $i$ ) a cartilage layer, composed of agarose hydrogel; $i$ ) a bone layer, made by microspheres of polylactideco-glycolide (PLGA) and 45S5 bioactive glass (BG), sintered together to form a 3D interconnected 
microsphere phase; iii) an interface region consisting of a hybrid phase of the previous ones [183]. Controlled chondrocytes and osteoblasts cultures on each scaffold region successfully resulted in the formation of three distinct yet continuous regions of cartilage, calcified cartilage and bone-like matrices.

Polymer-ceramic graded structures have also been designed for bone substitution. Liao et al. [184] fabricated a three-layer graded scaffold by layer-by-layer solvent casting method. It consists in: $i$ ) a polylactic-co-glycolic acid (PLGA) layer, ii) an intermediate layer made of carbonate apatitecollagen-PLGA composite with $4 \mathrm{wt} \%$ of apatite and iii) a layer made of the same composite with 8 wt $\%$ of apatite.

\section{Porosity graded ceramics for biomedical applications}

Within the porosity graded materials, the volume, shape and size of the pores are designed and gradually varied, according to the targeted properties of the FGCs.

As explained in section 2, to mimic the bimodal structure of the bone (cortical and cancellous, respectively), a biomedical implant should be designed with a porosity gradient from inner to outer layers. Pores with a particular dimension and morphology are essential requirement for osteoconduction, whereas the strength is inversely dependent on macro-porosity volume $[185,186]$. In addition, if a scaffold is designed to undergo a bioresorbability process, then the desired rate of degradation should be taken into account when the porosity is assessed. In fact, scaffolds fabricated from biomaterials with a high degradation rate should not have high porosities, since rapid depletion of the biomaterial will compromise the mechanical and structural integrity before substitution by newly formed bone. In contrast, scaffolds fabricated from biomaterials with low degradation rates and significant mechanical properties can be highly porous, because the higher pore surface area interacting with the host tissue can accelerate degradation [70].

Keeping in mind such features, Wang et al. developed a novel calcium phosphate-based biodegradable scaffold, characterized by a porosity gradient structure [185]. The dense outer layer was connected with the most porous one ( $60 \mathrm{vol} \%$ of pores) by a middle layer, having an intermediate porosity (30 vol\%). As a reference, a homogeneous, monolithic calcium-phosphate porous scaffold ( $\sim 33$ vol\% of pores) was prepared as well. To evaluate the degradability, both scaffolds were placed into a Tris- $\mathrm{HCl}$ buffer solution $\left(\mathrm{pH}=7.4\right.$, temperature $=37^{\circ} \mathrm{C}$ ) for a time ranging from 1 to 28 days. It was found that both materials presented the same degradation rate and amount (weight loss $\sim 10 \%$ after 28 days of testing). On the opposite, a clear difference in mechanical properties was assessed. In the graded scaffold, the compressive strength was almost the double as compared to the monolithic material in the starting, un-degraded condition. In addition, after 28 days of immersion test, the 
compressive strength decreased of $53 \%$ and $17 \%$ for the homogeneous and graded scaffolds, respectively. The authors suggested a potential application of the graded scaffold in large segmental bone implants.

Recently, Lee et al. have developed porous HA scaffolds with porosity-graded structures by sequential freeze-casting process. HA/camphene slurries with different HA contents $(10,15,20,25$, 40 , and $50 \mathrm{vol} \%$ ) were prepared by ball milling at $60^{\circ} \mathrm{C}$, poured into a cylindrical moulds and solidified at $42^{\circ} \mathrm{C}$ [46]. To achieve the desired gradation, HA slurries at the higher solid contents were cast around previously solidified HA suspensions at lower solid loading. Then, the two-layer green bodies were freeze dried to sublimate the camphene and generate pores. After sintering at $1250^{\circ} \mathrm{C} / 2 \mathrm{~h}$, the final graded scaffolds were obtained. In Figure 3 [46] we can appreciate the optical (A), micro computed tomography (micro-CT) (B) and SEM (C,D) images of a two-layer material, characterized by a continuous and homogeneous interface between the dense and the porous parts, without significant processing flaws or delamination phenomena. The porosity amount showed an almost linear dependence with the HA content in the initial slurry. Micro-CT analysis shows that the interconnectivity of the porous regions was greater than $99 \%$, due to the dendritic growth of camphene, which generated open pores upon sublimation. The compressive strengths were modulated by changing the relative thicknesses of the dense/porous parts. In particular way, the compressive strength increased from 7 to $47 \mathrm{MPa}$ when the above thickness ratio increased from 0 to 3 . In such a way, the authors demonstrated the feasibility of the method to customize the structural feature of the scaffold, thus to match those of the surrounding bone. Finally, the graded scaffold showed excellent biocompatibility, with cells viability and proliferation significantly higher as compared to monolithic tricalcium phosphate, used as a control.

Recently, the authors have developed an innovative calcium phosphate/polycaprolactone (PCL) scaffold, characterized by a gradation in both composition and porosity fraction [187]. The scaffold is made of $i$ ) a dense HA/ $\beta$-TCP core, ii) a macroporous, intermediate HA/ $\beta$-TCP layer and iii) a macroporous $\mathrm{PCL} /(\mathrm{HA} / \beta-\mathrm{TCP})$ external layer. The concept behind this design is to provide both mechanical strength - thanks to the dense calcium phosphate core, and an active environment towards the living tissue thanks to the porous polymer-based layer. In addition, an increased amount of $\beta$-TCP as respect to HA, moving from the inner to the outer layer is designed, with the aim to maximize the mechanical strength of the core and the bioresorbability of the external layer [188-190]. The major point of innovation of this structure, as compared to previous literature on porosity graded structures $[46,185,186]$ is the joining - in a simple but effective way - of an external polymer layer to an inner ceramic one. The ceramic layers were fabricated by gel-casting, according to some previous experiences related to both dense and porous samples [191-193], whereas the composite layer was 
obtained by a solvent casting/particle leaching process. A gradation in porosity amount was therefore achieved: relative densities of about $80 \%, 35 \%$ and $25 \%$ were respectively obtained, moving from the inner ceramic core to the outer polymer/ceramic layer. A part from the transition from the ceramic to the porous layer, a gradation within the HA/ $\beta$-TCP weight ratio was achieved: from 56/44 into the ceramic core, to $44 / 56$ into the transition ceramic layer and to a final $31 / 69$ into the external polymer layer. In Figure 4, some images of the three-layer structure are depicted.

As the scaffolds presented above, many porosity-graded structures were fabricated by adapting conventional processes usually used for porous materials: freeze-drying, use of porogens, foaming of a suspension, replication of a sponge [86]. The use of porogens involves the stacking of different layers containing different volume fractions and/or particle size of pore formers. This technique was successfully used to obtain HA with a pore size range of $700 \mu \mathrm{m}$ and pore volume fraction range of 70-89 \% [194]. The replication method can be also adapted for FGCs: Tampieri et al. made a twolayer HA scaffold with two different porous zones resulting from impregnation of polymeric sponge by two different HA slurries [94]. Although extensive research has been conducted, conventional manufacturing techniques still exhibit some limitations especially for more and more complex graded structures. To overcome these drawbacks, rapid prototyping (RP) has been proposed in the last decades. It can be defined as a layer-by-layer building of structures following a computer-aided design (CAD) model. Several advantages over conventional methods are remarkable: repeatability of the process, control of the scaffold architecture at the macro-scale (final shape) and micro-scale (porosity fraction, distribution, shape, size) [86], customized and patient-tailored scaffolds. It includes Fused Deposition Modelling (FDM), stereolithography, Selective Laser Sintering (SLS), 3D Printing (3DP).

Sherwood et al. [109] used a TheriForm ${ }^{\mathrm{TM}}$ three-dimensional printing process, which consists on selectively binding powder process through a liquid binder, thus to form solid three-dimensional objects, one layer at a time. The aim was to design and develop an osteochondral scaffold, requiring a rigid control of pore size. In fact, large pore sized part is to be implanted into bone for bone ingrowth, whereas the small pore sized part is to allow cartilage to grow in. In other words, the graded porous implant can be used to select or promote attachment of specific cell types in the implant prior to and/or after implantation [186]. In this specific case, the powder beds were made by polymer/porogen or polymer/ceramic/porogen mixtures. The selected polymer was PLGA, the ceramic phase was tricalcium phosphate (TCP) and the porogen was $\mathrm{NaCl}$, which was then leached by immersion in water, leading to the desired porous structure. The porosity was varied by changing the amount of $\mathrm{NaCl}$ across the scaffold. The upper (cartilage) region was highly porous (90 vol\%) and was composed of ${ }_{D, L}-P L G A / L-P L A$, with macroscopic channels to facilitate homogenous cell 
seeding. The lower, cloverleaf-shaped bone portion has a lower porosity (55 vol\%) and consisted of a L-PLGA/TCP composite, designed to maximize bone ingrowth while maintaining sufficient mechanical properties. The transition region between these two sections contained a gradient of materials and porosity, able to prevent delamination. The difference in the porosity level and size was opportunely designed to guide the chondrocytes activities and to facilitate the mineralized bone ingrowth. In fact, chondrocytes preferentially attached to the cartilage portion of the device, and biochemical and histological analyses showed that cartilage formed during a 6-week in vitro culture period. The tensile strength of the bone region was similar in magnitude to fresh cancellous human bone, suggesting that these scaffolds have desirable mechanical properties for in vivo applications, including full joint replacement.

Polypropylene- $\beta$-TCP graded scaffolds were fabricated by FDM by Kalita et al [195] for bone substitution. The structures were made of concentric cylinders with a variation of pore size or shape from centre to periphery. In FDM, the part is built by extruding filaments of materials from an extrusion nozzle to create layers. Pore shape and size were obtained by varying the FDM processing parameters during the process.

Selective laser sintering (SLS) is another rapid prototyping process in which a laser sinters small particles of polymeric, ceramic, or glass powders into a dense component [86]. The laser selectively sinters powdered material by scanning the surface of a powder bed following a 3D CAD model. Different polymer/ceramic composites have been obtained for bone substitution, as PCL/HA [108] or poly(ether-ether-ketone)/HA [196].

Stereolithography is a process in which a laser scans the surface of a light-sensitive resin according to a 3D computer model. The resin solidifies after exposure to the laser and this forms a layer of the final 3D structure. The process is repeated for each layer of the sample to produce. To produce ceramic parts, a light-sensitive ceramic suspension containing the ceramic powder, the resin and binders is used. This strategy was used to fabricate $\beta$-TCP porous part of an osteochondral scaffold by Bian et al. [197]. This part is the bone part of the osteochondral junction while the cartilage part was fabricated by gel-casting of type I collagen. Finally both parts were bonded by freeze-drying to obtain the final osteochondral junction.

\section{Microstructural graded ceramics for biomedical applications}

Microstructural graded materials are another type of FGCs, where the microstructure is tailored to achieve different functionalities and properties.

By applying this approach, Zhou et al. [45] developed a novel functionally graded HA bioceramic, in which the grain size varied from the micro to the nano range. Such innovative structure was 
conceived on the ground of the enhanced properties shown by nanocrystalline HA ceramics as compared to conventional, micronic ones. This includes increased mechanical properties [198, 199] and better biological performance, as attested by both in vitro and in vivo tests [193, 200]. Nano-HA showed, in fact, increased bioactivity towards cells and tissues, probably due to its similarity to chemical composition and mineral structure of bone tissue. In its nanocrystalline form, HA improves the biomineralization process [201], promotes ion exchange within a physiological environment, increases protein adsorption and cellular response [45]. A nanocrystalline HA powder (grain size in the range 50-80 nm), synthesized by wet-chemical method, was pressed and sintered by a two-step sintering method, according to previous studies [202]. In this process, samples are first heated at a high temperature (T1), to achieve relatively high density, and then cooled down to an intermediate temperature (T2) at which densification prevails over grain growth. By proper optimization of the sintering schedule, HA ceramics characterized by a graded microstructure were obtained: an outer layer, with HA grains of 60-80 $\mathrm{nm}$ in size, an inner layer made by 0.5-2.0 $\mu \mathrm{m}$-sized HA grains, a transition layer showing grains of both size ranges. A simulation of the local temperature distribution inside the sample showed a progressive decrease of the temperature moving from inner to outer layers, responsible of the gradation in grain size.

Morsi et al. succeeded in fabricating $\mathrm{Al}_{2} \mathrm{O}_{3}$ samples for orthopaedic applications characterized by a continuous decreasing of the grain size along its thickness [47]. Several batches of commercial $\alpha$ $\mathrm{Al}_{2} \mathrm{O}_{3}$ powders, with size of 50,100, 150 and $250 \mathrm{~nm}$ respectively, were ball-milled and used in a sequentially slip casting process. So, the slips were cast in plastic moulds placed on a plaster of Paris base, to form a graded green compact, with layers of increasing grain size along the height. After hotpressing, nearly full dense ceramics characterized by a gradient in grain size (from about $380 \mathrm{~nm}$ in the inner layer to $580 \mathrm{~nm}$ in the outer one) were achieved. At the same time, a hardness profile exhibiting a gradual transition along the thickness of the materials (the finer the grain size, the higher the hardness) was successfully obtained.

$\mathrm{Si}_{3} \mathrm{~N}_{4}$ is gaining increasing attention as a biomedical-grade ceramic. Besides high strength and fracture toughness, it is biocompatible, stable in vivo and visible on X-ray radiographs. It is already clinically used for spinal fusion implants and it is being developed for other biomedical applications such as bearings in hip and knee arthroplasty and dental implants [203]. One important advantage of $\mathrm{Si}_{3} \mathrm{~N}_{4}$ ceramics is the possibility to tailor their microstructures and, consequently, their properties, by controlling the $\alpha \rightarrow \beta$ phase transformation that occurs during sintering at high temperature [204, 205]. In fact, the growth of large, elongated $\beta-\mathrm{Si}_{3} \mathrm{~N}_{4}$ grains of high aspect ratio - starting from the finer, equiaxed $\alpha-\mathrm{Si}_{3} \mathrm{~N}_{4}$ ones, produces an in situ toughening mechanism [206, 207], although the material becomes less hard due to the decreasing $\alpha$-phase content. The control of this phase 
transformation, leading to phase gradients in the specimens, would open great technological possibilities, such as high toughness and hardness values in a single specimen. To this aim, Belmonte et al. fabricated graded $\mathrm{Si}_{3} \mathrm{~N}_{4}$ materials using SPS as a densification technique [204]. Here, a modified configuration of the SPS machine was employed, in which the contact sections between the plungers and die were varied, to gain control of the current intensity and hence the temperature profile inside the specimens. In such a way, the degree of $\alpha \rightarrow \beta$ phase transformation in $\mathrm{Si}_{3} \mathrm{~N}_{4}$ ceramics was tailored, and hence their microstructure and properties. After sintering at $1650^{\circ} \mathrm{C}$, fully dense, graded materials were obtained. The $\alpha$-phase content gradually increased along the cross section of the material, from a starting $4 \mathrm{vol} \%$ in the top surface to a final $61 \mathrm{vol} \%$ in the bottom one. As a consequence, a graded microstructure was produced, in which the average grain size decreased from $\sim 500 \mathrm{~nm}$ in the low- $\alpha$-phase layer, to $\sim 200 \mathrm{~nm}$ in the rich- $\alpha$-phase layer, accompanied by a similar decrease in aspect ratio (from 2.3 to 1.5). The hardness showed a clear evolution, increasing from the top to bottom surfaces, as the $\alpha$-phase content increased. As expected, the fracture toughness showed the opposite trend, with maximum values at the top surface, with the highest $\beta-\mathrm{Si}_{3} \mathrm{~N}_{4}$ content. Here, the elongated coarse grains are responsible of the material toughening effect, through different mechanisms which include pull-out, crack deflection and crack bridging.

As a last example, a very innovative approach was recently proposed by Le Ferrand et al., who developed heterogeneous/graded materials by exploiting a magnetically assisted slip casting process [208]. The authors proposed a new additive manufacturing route to create lamellar composites, with locally controlled texture. This was achieved by combining the slip-casting technology with a recently developed approach able to control the orientation and distribution of anisotropic particles, contained in the slurry, by applying magnetic fields. To this aim, the anisotropic particles were coated with superparamagnetic iron oxide nanoparticles (SPIONs), to become magnetically responsive [209]. The slip casting process led to the deposition of a cake on the surface of the porous mould. By applying an external magnetic field, it was possible to orient the anisotropic particles throughout the thickness of the cake. Changing the direction of the magnetic field, heterogeneous composites with any desired orientation of anisotropic particles throughout the thickness of the material were obtained. This approach was successfully used to reproduce the complex architecture of a biological tooth, as shown in Figure 5. The design of the structure is presented in (a), where - to mimic the dentin-enamel layers of a natural tooth - a two-layer structure, with differently oriented particles, is proposed. The material was then fabricated by sequentially casting two different aqueous suspensions into a porous mould, reproducing the tooth shape. The suspension used to mimic the dentin-like layer consisted of a mixture of alumina platelets (20 vol\%) and isotropic alumina nanoparticles (13 vol\%), suspended in a $5 \mathrm{wt} \%$ poly(vinyl pyrrolidone) aqueous solution. To obtain a denser and harder material in the outer 
enamel-like layer, 4 vol\% of isotropic alumina nanoparticles were replaced by $100 \mathrm{~nm}$ silica particles in the casting suspension. Silica was used to produce a liquid phase during sintering, increasing the bonding strength among the platelets. The casting procedure was carried out in the presence of a rotating magnetic field, thus to replicate the orientation of reinforcing elements found in natural teeth: perpendicular to the cusp surface within the enamel layer and parallel to the surface in the underlying dentin layer. After sintering, the two-layer structure was polymer-infiltrated to create a tooth-like complex-shaped composite with 50 and 64 vol\% inorganic phase in dentin-like and enamel-like layers, respectively (b). As shown by the electron diffraction X-ray mapping (c), Si atoms are exclusively present in the outer enamel-like layer, while Al atoms were present in both layers. Microhardness measurements of the material across the boundary between the enamel- and dentin-like layers showed a continuous decrease of the hardness from the enamel-like layer to the bilayer interface, before reaching a lower plateau value at the dentin-like side, similarly to the DEJ of natural tooth. This gradual transition was imputed to the change in platelets orientation and density across the bilayer interface, as shown in (d). This technology appears as an effective approach to generate multi-layered composites with mechanical properties that can potentially outperform the most stateof-the-art dental materials.

\section{Conclusion and future directions}

Object of this review was to illustrate the potential of the innovative multilayer and graded structures for $i$ ) achieving better integration with the surrounding tissues, $i i$ ) joining mechanical strength with biological (and/or other) functions, iii) promoting and guiding the activity of different cells, $i v$ ) enabling the regeneration of multi-tissues. All these aspects have been addressed in paragraphs 3-5: the reported examples proved the feasibility to achieve improved or additional functionalities in new graded scaffolds whose design (gradation of porosity, composition or microstructure, or even a combination of such features) was optimized according to the targeted properties. We are therefore assisting to the development of a new generation of scaffolds and devices, with a potential strong impact in both hard and hard/soft tissues surgery.

However, many challenges still remain, which should be properly addressed to translate the promising laboratory experimentations to clinical successes.

With reference to osteochondral tissue regeneration, although the several strategies to establish the osteochondral interface, it is still a major challenge to produce a seamless bone-cartilage interface that is similar to the native osteochondral tissue. It is in fact extremely complicated to realize a continuously gradient structure that allow smooth bone-cartilage interface formation. With reference to bone tissue, we can see that most of the efforts are oriented to design and develop scaffolds with a 
gradation in density from inner to outer layers (e.g., dense core and porous surface) which is inverse to the bone architecture, thus still far from mimicking the real bio-mechanics of natural bone.

In this field, computational models play a key role to predict the properties and modulate them upon the layer-by-layer variation of the structure. Thus, on one hand, it is imperative to dedicate extra efforts to generate reliable predictive models, useful to optimize the design of the graded structures and shorten the development stage. On the other hand, moving from mathematical models to the fabrication of the graded materials is a further necessary step. In the field of dental materials, for example, it is striking the gap between the numerous papers dedicated to simulate the properties into graded junction between enamel and dentin and the few graded structures already developed. More in general, there is still a lack of integration between design of customized FGCs and subsequent fabrication. The papers that combine simulation and prototypal production are indeed very few.

Scaling up of these complex scaffolds represents another essential step towards clinical utilization. In this frame, substantial research dealing with long-term clinical follow-up, possibly with larger animal models, are required before these novel approaches could find clinical applications.

Finally, the new CAD-CAM driven technologies show a great potential for FGCs, allowing patientoriented design of the prosthetic devices and their manufacturing with a high degree of complexity and precision. Moreover, the recent advances in 3D printing techniques promote the achievement of components with controlled micro- and macro-architectural features and their gradation over the different layers of the structures. In addition, they allow to dynamically mix, grade and vary the ratios of different materials, resulting in continuous gradients and structurally optimized designs with efficient use of materials, reductions in waste and production of highly customizable features.

\section{Acknowledgment}

The authors wish to acknowledge Labormet Due srl, Torino, Italy, for the images of stereomicroscopy.

\section{References}

[1] Henriques B. Inhomogeneous materials perform better: functionally graded materials for biomedical applications. J. Powder Metall. Min. 2013;2:1-2.

[2] Besisa D.H.A., Ewais E.M.M. Advances in functionally graded ceramics - Processing, sintering properties and applications. In: Ebrahimini F, ed., Chapter 1 in Advances in Functionally Graded Materials and Structures. InTech; 2016:1-31.

[3] Sola A., Bellucci D., Cannillo V., Functionally graded materials for orthopaedic applications - an update on design and manufacturing. Biotechnol. Adv. 2016;34:504-531. 
[4] Pompe W., Worch H., Epple M. et al. Functionally graded materials for biomedical applications. Mater. Sci. Eng. A 2003;362:40-60.

[5] El-Wazery M.S., El-Desouky A.R. A review on functionally graded ceramic-metal materials. Mater. Environ. Sci. 2015;6:1369-1376.

[6] Fitzer E., Gadow R., Somiya S. et al. Proceedings of International Symposium on Ceramic Components for Engineering, KTK Scientific Publishers, Tokyo, Japan (1983) p. 561.

[7] Schlichting J. Molybdändisilizid als Komponente moderner Hochtemperaturwerkstoffe. High Temp. High Press. 1978;10:241-269.

[8] Koizumi M., Niino M. Overview of FGM research in Japan. MRS Bull. 1995;1:19-21.

[9] Sasaki M., Hirai T. Fabrication and properties of functionally gradient materials. J. Ceram. Soc. Japan. 1991;99:1002-1013.

[10] Basu S.N., Kulkarni T., Wang H.Z., Sarin V.K. Functionally graded chemical vapor deposition mullite environmental barrier coatings for Si-based ceramics. J. Eur. Ceram. Soc. 2008;28:437-445. [11] Saremi M., Valefi Z. Thermal and mechanical properties of nano-YSZ-Alumina functionally graded coatings deposited by nano-agglomerated powder plasma spraying. Ceram. Int. 2014;40:13453-13459.

[12] Kobayashi A. Functionally graded thermal barrier composite coatings formed by gas tunnel type plasma spraying. IEPC03, March 2003, Toroth, France. https:// http://erps.spacegrant.org/uploads/images/images/iepc_articledownload_198807/2003index/00410303iepc-full.pdf

[13] Limarga A.M., Widjaja S., Yip T.H. Mechanical properties and oxidation resistance of plasmasprayed multilayered $\mathrm{Al}_{2} \mathrm{O}_{3} / \mathrm{ZrO}_{2}$ thermal barrier coatings. Surf. Coat. Technol. 2005;197:93-102.

[14] Negahdari Z., Willert-Porada M., Scherm F. Development of novel functionally graded $\mathrm{Al}_{2} \mathrm{O}_{3}-$ lanthanum hexaaluminate ceramics for thermal barrier coatings. Mater. Sci. Forum. 2010;631632:97-102.

[15] Carpio P., Salvador M.D., Borrell A., Sánchez E. Thermal behaviour of multilayer and functionally-graded $\mathrm{YSZ} / \mathrm{Gd}_{2} \mathrm{Zr}_{2} \mathrm{O}_{7}$ coatings. Ceram. Int. 2017;43:4048-4054.

[16] Gok M.G., Goller G. Microstructural characterization of GZ/CYSZ thermal barrier coatings after thermal shock and CMAS+hot corrosion test. J. Eur. Ceram. Soc. 2017;6:2501-2508.

[17] Wang C., Wang Y., Fan S. et al. Optimized functionally graded $\mathrm{La}_{2} \mathrm{Zr}_{2} \mathrm{O}_{7} / 8 \mathrm{YSZ}$ thermal barrier coatings fabricated by suspension plasma spraying. J. Alloys Comp. 2015;649:1182-1190.

[18] Chen X., Gu L., Zou B., et al. New functionally graded thermal barrier coating system based on $\mathrm{LaMgAl}_{11} \mathrm{O}_{19} / \mathrm{YSZ}_{\mathrm{S}}$ prepared by air plasma spraying. Surf. Coat. Technol. 2012;206:2265-2274. 
[19] Khan M.A., Duraiselvam M., Panwar S.S. et al. Improvement of strain tolerance of functionally graded TBCs through laser surface micro-texturing. J. Mat. Sci. 2017;52:696-708.

[20] Zhao S., Zhao Y., Zou B. et al. Characterization and thermal cycling behavior of $\mathrm{La}_{2}\left(\mathrm{Zr}_{0.7} \mathrm{Ce}_{0.3}\right)_{2} \mathrm{O}_{7} / 8 \mathrm{YSZ}$ functionally graded thermal barrier coating prepared by atmospheric plasma spraying. J. Alloys Comp. 2014;592:109-114.

[21] Kimberly F.R, Oo Z., Sujan D. Microstructure analysis, physical and thermal properties of $\mathrm{Al}_{2} \mathrm{O}_{3}-\mathrm{Al}_{2} \mathrm{TiO}_{5}$ functionally graded ceramics for the application of car brake tot. Pertanika J. Sci. Technol. 2015;23:153-161.

[22] Mouchon E., Colomban P.H. Microwave absorbent, preparation, mechanical properties and r.fmicrowave conductivity of $\mathrm{SiC}$ (and/or mullite) fiber reinforced Nasicon matrix composites. J. Mater. Sci. 1996;31:323-334.

[23] Huang C.-Y., Chen Y.-L. Design and impact resistant analysis of functionally graded $\mathrm{Al}_{2} \mathrm{O}_{3}$ $\mathrm{ZrO}_{2}$ ceramic composite. Mater. Des. 2016;91:294-305.

[24] Li L., Chengn L., Fann S., et al. Fabrication and dynamic compressive response of laminated $\mathrm{ZrO}-\mathrm{Zr}_{2} \mathrm{CN} / \mathrm{Si}_{3} \mathrm{~N}_{4}$ ceramics. Ceram. Int. 2015;41:8584-8591.

[25] Zhao J., Ai X., Deng J., et al. Thermal shock behaviors of functionally graded ceramic tool materials. J. Eur. Ceram. Soc. 2004;24:847-854.

[26] Schulz H., Peters M., Bach F.W., et al. Graded coatings for thermal, wear and corrosion barriers. Mater. Sci. Eng. A. 2003;362:61-80.

[27] Eso O., Fang Z., Griffo A. Liquid phase sintering of functionally graded WC-Co composites. Int. J. Refract. Metals Hard. Mater. 2005;23:233-241.

[28] Lengauer W., Dreyer K. Functionally graded hardmetals. J. Alloys Comp. 2002;338:194-212.

[29] Zheng G., Zhao J., Gao Z., et al. Cutting performance and wear mechanisms of Sialon-Si $\mathrm{N}_{4}$ graded nano-composite ceramic cutting tools. Int. J. Adv. Manuf. Technol. 2012;58:19-28.

[30] Çaliş N., Kuşhan Ş.R., Kara F. et al. Functionally graded SiAlON ceramics. J. Eur. Ceram. Soc. 2004;24:3387-3393.

[31] Ewais E.M.M., Besisa D.H.A., Zaki Z.I. et al. Tailoring of functionally graded zirconiamullite/alumina ceramics. J. Eur. Ceram. Soc. 2012;32:1561-1573.

[32] Chen L., Kny E., Groboth G. SiAlON ceramics with gradient microstructures. Surf. Coat. Technol. 1998;100-101;320-323.

[33] Lee C.S., Ahn S.H., DeJonghe L.C. et al. Effect of functionally graded material (FGM) layers on the residual stress of polytypoidally joined $\mathrm{Si}_{3} \mathrm{~N}_{4}-\mathrm{Al}_{2} \mathrm{O}_{3}$. Mater. Sci. Eng. A. 2006;34:160-165.

[34] Bartolomé J.F., Moya S., Requena J. et al. Fatigue crack growth behavior in mullite/alumina functionally graded ceramics. J. Am. Ceram. Soc. 1998;81:1502-1508. 
[35] Rosler J., Tonnes C. Processing of TiAl components with gradient microstructures. In Proc. of the third Int 'I. symp. on structural and functional gradient materials,

(eds. B. Ilschner and N. Cherradi), Presses Polytechniques et Universitaires Romandes, Lausanne, 41-46, (1995).

[36] Cramer C.R., Gonzalez-Julian J., Colasuonno P.S. et al. Continuous functionally graded material to improve the thermoelectric properties of ZnO. J. Eur. Ceram. Soc. 2017;37:4693-4700.

[37] Bharti I., Gupta N., Gupta K.M. Novel applications of functionally graded nano-optoelectronic and thermoelectric materials. Int. J. Mater. Mech. Manufact. 2013;1:221-224.

[38] Navarro A., Whatmore R.W., Alcock J.R. Preparation of functionally graded PZT ceramics using tape casting. J. Electroceram. 2004;13:413-415.

[39] Derayatifar M., Tahani M., Moeenfard H. Nonlinear analysis of functionally graded piezoelectric energy harvesters. Compos. Struct. 2017;182:1998.

[40] Drochel M., Oberacker R., Hoffmann M.J. Processing of silicon carbide evaporators with porosity gradients by pressure filtration. In: Functionally graded materials 1998, ed.W.A.Kaysser, Mater. Sci. Forum, vols. 308-311, Trans Tech.

[41] Liu Z., Liu M., Nie L. et al. Fabrication and characterization of functionally-graded LSCF cathodes by tape casting. Int. J. Hydrogen Energy. 2013;38:1082-1087.

[42] Ichinose N., Miyamoto N., Takahashi S. Ultrasonic transducers with functionally graded piezoelectric ceramics. J. Eur. Ceram. Soc. 2004;24:1681-1685.

[43] Zha S., Zhang Y., Liu M. Functionally graded cathodes fabricated by sol-gel/slurry coating for honeycomb SOFCs. Solid State Ionics. 2005;176:25-31.

[44] Wosko M., Paszkiewicz B., Piasecki T. et al. Application of functionally graded materials in optoelectronic devices. Opt. App. 2005;35:663-667.

[45] Zhou C., Deng C., Chen X. Mechanical and biological properties of the micro-/nano-grain functionally graded hydroxyapatite bioceramics for bone tissue engineering. J. Mech. Behav. Biomed. 2015;28:1-11.

[46] Lee H., Jang T.S., Song J., et al. The production of porous hydroxyapatite scaffolds with graded porosity by sequential freeze-casting. Materials 2017;10:367-139.

[47] Morsi K., Keshavan H., Bal S. Hot pressing of graded ultrafine-grained alumina bioceramics. Mater. Sci. Eng. A. 2004;386:384-389.

[48] Anné G., Vanmeensel K., Vleugels J. et al. Electrophoretic deposition as a novel near net shaping technique for functionally graded biomaterials. Mater. Sci. Forum 2005;492-493:213-218.

[49] Ginter P., Watjen A.M., Kramer M. et al. Functionally graded ceramic structures by direct thermal inkjet printing. J. Ceram. Sci. Tech. 2015;6:119-124. 
[50] Sun L., Sneller A., Kwon P. Fabrication of alumina/zirconia functionally graded material: from optimization of processing parameters to phenomenological constitutive models. Mat. Sci. Eng. A. 2008;488:31-38.

[51] Afzal M.A.F., Kesarwani P., Reddy K.M. et al. Functionally graded hydroxyapatite-aluminazirconia biocomposite: Synergy of toughness and biocompatibility. Mat. Sci. Eng. C. 2012;32:11641173.

[52] Askari E., Mehrali M., Metselaar I.H.S.C. et al. Fabrication and mechanical properties of $\mathrm{Al}_{2} \mathrm{O}_{3} / \mathrm{SiC} / \mathrm{ZrO}_{2}$ functionally graded material by electrophoretic deposition. J. Mech. Behav. Biomed. 2012;12:144-150.

[53] Guo H., Khor K.A., Boey Y.C., et al. Laminated and functionally graded hydroxyapatite/yttria stabilized tetragonal zirconia composites fabricated by spark plasma sintering. Biomaterials. 2003;24:667-675.

[54] Cannillo V., Manfredini T., Siligardi C. et al. Preparation and experimental characterization of glass-alumina functionally graded materials. J. Eur. Ceram. Soc. 2006;26:993-1001.

[55] Zhang Y., Sun M., Zhang D. Designing functionally graded materials with superior load-bearing properties. Acta Biomaterialia 2012;8:1101-1108.

[56] Tsukada G., Sueyoshi H., Kamibayashi H. Bending strength of zirconia/porcelain functionally graded materials prepared using spark plasma sintering. J. Dent. 2014;42:1569-1576.

[57] Kaya C. $\mathrm{Al}_{2} \mathrm{O}_{3}-\mathrm{Y}-\mathrm{TZP} / \mathrm{Al}_{2} \mathrm{O}_{3}$ functionally graded composites of tubular shape from nano-sols using double-step electrophpretic deposition. J. Eur. Ceram. Soc. 2003;23:1655-1660.

[58] Mehrali M., Seyed Shirazi M., Mehrali M. et al. Dental implants from functionally graded materials. J. Biomed. Mater. Res. A. 2013;101:3046-3057.

[59] Shi J. Development of functionally graded implant materials in commercial use. MPRA (Munich Personal RePEc Archive) Paper No. 76351, posted 22 January 2017 14:54 UTC. https://mpra.ub.unimuenchen.de/76351/

[60] Flynn C.O., McCormack B.A.O. A three-layer model of skin and its application in simulating wrinkling. Comput. Method. Biomec. 2009;12:125-134.

[61] Seidi A., Ramalingam M., Elloumi-Hannachi I., et al. Gradient biomaterials for soft-to-hard interface tissue engineering. Acta Biomater. 2011;7:441-1451.

[62] Genin G.M., Kent A., Birman V. et al. Functional grading of mineral and collagen in the attachment of tendon to bone. Biophys. J. 2009;97:976-985.

[63] He B., Wu J.P., Kirk T.B. High-resolution measurements of the multilayer ultra-structure of articular cartilage and their translational potential. Arthritis Research \& Therapy 2014;16:205-231. 
[64] Atesok K., Doral M.N., Karlsson J. et al. Multilayer scaffolds in orthopaedic tissue engineering. Knee Surg. Sports Traumatol. Arthrosc. 2016;24:2365-2373.

[65] Franzen A., Inerot S., Hejderup S.O., et al. Variations in the composition of bovine hip articular cartilage with distance from the articular surface. Biochem. J. 1981;195:535-543.

[66] Madry H., van Dijk C.N., Mueller-Gerbl M. The basic science of the subchondral bone. Knee Surg. Sports Traumatol. Arthrosc. 2010;18:419-433.

[67] Keeney M., Pandit A. The osteochondral junction and its repair via bi-phasic tissue engineering scaffolds. Tissue Eng. Part B Rev. 2009;15:55-73.

[68] Nooeaid P., Salih V., Beier J.P. et al. Osteochondral tissue engineering: scaffolds, stem cells and applications. J. Cell. Mol. Med. 2012;16:2247-2270.

[69] Cowin S.C., Gailani G., Benalla M. Hierarchical poroelasticity: movement of interstitial fluid between porosity levels in bones. Phil. Trans. R. Soc. A. 2009;367:3401-3444.

[70] Karageorgiou V., Kaplan D. Porosity of 3D biomaterial scaffolds and osteogenesis. Biomaterials, 2005;26:5474-5491.

[71] Simske S.J., Ayers R.A., Bateman T.A. Porous materials for bone engineering. Mat. Sci. Forum 1997;250:151-182.

[72] Sprio S., Ruffini A., Valentini F. et al. Biomimesis and biomorphic transformations: new concepts applied to bone regeneration. J. Biotech. 2011;156:347-355.

[73] Murugan R., Ramakrishna S. Development of nanocomposites for bone grafting. Compos. Sci. Tech. 2005;65:2385-2406.

[74] Wu S., Liu X., Yeung K.W.K, et al. Biomimetic porous scaffolds for bone tissue engineering. Mat. Sci. Eng. R., 2014;80:1-36.

[75] Keaveny T.M., Morgan E.F., Yeh O.C. Bone mechanics. In M. Kuts (Ed.), Standard Handbook of Biomedical Engineering and Design (Chapter 8). The McGraw-Hill Companies, Inc. 2003.

[76] Barrère F., Mahmood T.A., de Groot K. et al. Advanced biomaterials for skeletal tissue regeneration: Instructive and smart functions. Mater. Sci. Eng. R 2008;59:38-71.

[77] Porter J.R., Ruckh T.T., Popat K.C. Bone tissue engineering: a review in bone biomimetics and drug delivery strategies. Biotechnol. Prog. 2009;25:1539-1560.

[78] Katti K.S., Gu C., Katti D.R. Biomimetcs: Inspiration from the structural organization of biological systems. In J.J. Maya and T. Sabu (Eds.), Natural polymers: composites (Chapter 2). RSC Publishing. 2012.

[79] Palmero P. Ceramic-polymer nanocomposites for bone-tissue regeneration. In: H. Liu, ed. Chapter 15 in Nanocomposites for Musculoskeletal Tissue Regeneration. WP Woodhead Publishing, Elsevier;2016:331-367. 
[80] Chun K.J., Choi H.H., Lee J.Y. Comparison of mechanical property and role between enamel and dentin in the human teeth. J. Dent. Biomech. 2014;5:1-7.

[81] Zimmerman B., Datko L., Cupelli M. Alteration of dentin-enamel mechanical properties due to dental whitening treatments. J. Mech. Behav. Biomed. 2010;3:339-346.

[82] Giannini M., Soares C.J., Marins de Carvalho R. Ultimate tensile strength of tooth structures. Dent. Mater. 2004;20:322-329.

[83] Zhang F., Vanmeensel K., Inokoshi M. et al. 3Y-TZP ceramics with improve hydrothermal degradation resistance and fracture toughness. J. Eur. Ceram. Soc. 2014;34:2453-2463.

[84] Imbeni V., Kruzic J.J., Marshall G.W. et al. The dentin-enamel junction and the fracture of human teeth. Nat. Mater. 2005;4: 229-232.

[85] Xie Z.H., Swain M.V., Swadener G. et al. Effect of microstructure upon elastic behaviour of human tooth enamel. J. Biomech. 2009;42:1075-1080.

[86] Huang M., Rahbar N., Wang R. et al. Bioinspired design of dental multilayers. Mat. Sci. Eng. A. $2007 ; 464: 315-320$.

[87] Toschi F.C., Melandri P., Pinasco E., et al. Influence of residual stresses on the wear behaviour alumina/alumina-zirconia laminates. J. Am. Ceram. Soc. 2003;86:1547-1553.

[88] Novak S., Kalin M., Lukas P. The effect of residual stresses in functionally graded aluminaZTA composites on their wear and friction behaviour. J. Eur. Ceram. Soc. 2007;27:151-156.

[89] Lee B.-T., Kang I.C., Kumar Gain A. et al. Fabrication of pore-gradient $\mathrm{Al}_{2} \mathrm{O}_{3}-\mathrm{ZrO}_{2}$ sintered bodies by fibrous monolithic process. J. Eur. Ceram. Soc. 2006;26:3525-3530.

[90] Zhang Y., Kim J.W. Graded structures for damage resistant and aesthetic all-ceramic restorations. Dent. Mater. 2009;25:781-790.

[91] Fabris D., Souza J.C.M., Silva F.S. et al. The bending stress distribution in bilayered and graded zirconia-based dental ceramics. Ceram. Int. 2016;42:11025-11031.

[92] Matsuno T., Watanabe K., Ono K. et al.. Preparation of laminated hydroxyapatite/zirconia sintered composite with the gradient composition. J. Mater. Sci. Lett. 17;1998:1349-1351.

[93] Kim M., Franco R.A., Lee B.-T. Synthesis of functional gradient BCP/ZrO 2 bone substitutes using $\mathrm{ZrO}_{2}$ and BCP nanopowders. J. Eur. Ceram. Soc. 2011;31:1541-1548.

[94] Tampieri A., Celotti G., Sprio S. et al. Porosity-graded hydroxyapatite ceramics to replace natural bone. Biomaterials 2001;22:1365-1370.

[95] Chamary S., Hautcoeur D., Hornez J.-C. et al. Bio-inspired hydroxyapatite dual core-shell structure for bone substitutes. J. Eur. Ceram. Soc. 2017;37:5321-5327.

[96] Roncari E., Galassi C., Pinasco, P. Tape casting of porous hydroxyapatite ceramics. J. Mater. Sci. Lett. 2000;19:33-35. 
[97] Lindner M., Bergmann C., Telle R. et al. Calcium phosphate scaffolds mimicking the gradient architecture of native long bones. J. Biomed. Mater. Res. A 2014;102:3677-684.

[98] Rodriguez-Lorenzo L.M., Ferreira J.M.F. Development of porous ceramic bodies for applications in tissue engineering and drug delivery systems. Mater. Res. Bull. 2004;39:83-91.

[99] Lu W.W., Zhao F., Luk K.D.K. et al. Controllable porosity hydroxyapatite ceramics as spine cage: fabrication and properties evaluation. J. Mater. Sci. Mater. Med. 2003;14:1039-1046.

[100] Kon M., Ishikawa K., Miyamoto Y. et al. Development of calcium phosphate based functional gradient bioceramics. Biomaterials 1995;16:709-714.

[101] Wong L.H., Tio B., Miao X. Functionally graded tricalcium phosphate/fluoroapatite composites. Mater. Sci. Eng. C 2002;20:111-115.

[102] Manjubala I., Sivakumar M., Sampathkumar T.S. et al.. Synthesis and characterization of functional gradient materials using Indian corals. J. Mater. Sci. Mater. Med. 2000;11:705-709.

[103] Miao X., Hu Y., Liu J. et al. Hydroxyapatite coating on porous zirconia. Mater. Sci. Eng. C 2007;27:257-261.

[104] Stanic V., Nicoli Aldini N., Fini M. et al. Osteointegration of bioactive glass-coated zirconia in healthy bone: an in vivo evaluation. Biomaterials 2002;23:3833-384.

[105] Kim H.W., Lee S.Y., Bae C.J. et al. Porous $\mathrm{ZrO}_{2}$ bone scaffold coated with hydroxyapatite with fluorapatite intermediate layer. Biomaterials 2003;24:3277-3284.

[106] Kim C.Y., Soon Jee S. Hydroxyapatite formation on bioactive-glazed alumina. J. Eur. Ceram. Soc. 2003;23:1803-1811.

[107] Yamashita D., Sato H., Miyamoto M. et al. Hydroxyapatite coating on zirconia using glass coating technique. J. Ceram. Soc. Jpn 2008;116:20-22.

[108] Wiria F.E., Leong K.F., Chua C.K., et al. Polycaprolactone/hydroxyapatite for tissue engineering scaffold fabrication via selective laser sintering. Acta Biomater. 2007;3:1-12.

[109] Sherwood J.K., Riley S.L., Palazzolo R. A three-dimensional osteochondral composite scaffold for articular cartilage repair. Biomaterials 2002;23:4739-4751.

[110] Tampieri A., Sandri M., Landi E. Design of graded biomimetic osteochondral composite scaffolds. Biomaterials 2008;29:3539-3546.

[111] Levingstone T.J., Matsiko A., Dickson G.R. et al. A biomimetic multi-layered collagen-based scaffold for osteochondral repair. Acta Biomater. 2014;10:1996-2004.

[112] Laurenti K.C., de Albuquerque Haach L.C., dos Santos Jr. A.R. et al. Cartilage reconstruction using self-anchoring implant with functional gradient. Mater. Res. 2014;17:638-649.

[113] Muthutantri A., Huang J., Edirisinghe M. Novel preparation of graded porous structures for medical engineering. J. R. Soc. Interface 2008;5:1459-1467. 
[114] Leong K.F., Chua C.K., Sudarmadji N. et al. Engineering functionally graded tissue engineering scaffolds. J. Mech. Behav. Biomed. 2008;1:140-152.

[115] Nehrer S., Breinan H.A., Ramappa A. et al. Matrix collagen type and pore size influence behaviour of seeded canine chondrocytes. Biomaterials 1997;18:769-776.

[116] Miot S., Woodfield T., Daniels A.U. et al. Effects of scaffold composition and architecture on human nasal chondrocyte redifferentiation and cartilaginous matrix deposition. Biomaterials 2005;26:2479-2489.

[117] Oh S.H., Park I.K., Kim J.M., Lee J.H. In vitro and in vivo characteristics of PLC scaffolds with pore size gradient fabricated by a centrifugation method. Biomaterials 2007;28:1664-1671.

[118] Salem A.K., Stevens R., Pearson R.G. et al. Interactions of 3T3 fibroblasts and endothelial cells with defined pore features. J. Biomed. Mater. Res. 2002;61:212-217.

[119] Galarneau L., Loranger A., Gilbert S., et al. Keratins modulate hepatic cell adhesion, size and G1/S transition. Experimental Cell Research 2007;313:179-194.

[120] Oota Y., Ono K., Miyazima S. 3D modeling for sagittal suture. Physica A 2006;359:538-546.

[121] Tanaka M., Takayama A., Ito E. et al. Effect of pore size of selforganized honey comb patterned polymer films on spreading, focal adhesion, proliferation, and function of endothelial cells. J. Nanosci. Nanotech. 2007;7:763-772.

[122] Wang H., Pieper J., Péters F. et al. Synthetic scaffold morphology controls human dermal connective tissue formation. J. Biomed. Mater. Res. 2005;74A:523-532.

[123] Yang S.F., Leong K.F., Du Z.H. et al. The design of scaffolds for use in tissue engineering. Part 1, traditional factors. Tissue Eng. 2001;7:679-689.

[124] Zarone F., Russo S., Sorrentino R. From porcelain-fused-to-metal to zirconia: clinical and experimental considerations, Dent. Mater. 2011;27:83-96.

[125] Willmann G. Medical-grade alumina during the past two decades, Bioceramics 1994;7:359364.

[126] Conrad H.J., Seong W.J., Pesun I.J. Current ceramic materials and systems with clinical recommendations: a systematic review. J. Prosthet. Dent. 2007;98:389-404.

[127] Baldassarri M., Zhang Y., Thompson V.P. et al. Reliability and failure modes of implantsupported zirconium-oxide fixed dental prostheses related to veneering techniques. J. Dent. 2011;39:489-498.

[128] Choi J.E., Waddell J.N., Swain M.V. Pressed ceramics onto zirconia. Part 2: indentation fracture and influence of cooling rate on residual stresses. Dent. Mater. 2011;27:1111-1118.

[129] Swain M.V. Unstable cracking (chipping) of veneering porcelain on all-ceramic dental crowns and fixed partial dentures. Acta Biomater. 2009;5:1668-1677. 
[130] Henriques B., Miranda G., Gasik M. et al. Finite element analysis of the residual thermal stresses on functionally gradated dental restorations, J. Mech. Behav. Biomed. Mater. 2015;50:123130.

[131] Madfa A.A., Yue X.G. Dental prostheses mimic the natural enamel behavior under functional loading: A review article. Jpn Dent. Sci. Rev. 2016;52:2-13.

[132] Zhang Y. Overview: Damage resistance of graded ceramic restorative materials. J. Eur. Ceram. Soc. 2012;32:2623-2632.

[133] Raucci M.G., Giugliano D., Ambrosio L. Fundamental properties of bioceramics and biocomposites. (2016) In: Antoniac I. (eds) Handbook of Bioceramics and Biocomposites. Springer, Cham, pp 35-58, DOI: 10.1007/978-3-319-12460-5_3.

[134] Narayan R.J. Monitoring and evaluation of biomaterials and their performance In Vivo, Editors: Roger Narayan, 2016.

[135] Maccauro G., Rossi Iommetti P., Raffaelli L., Manicone P.F. Alumina and zirconia ceramic for orthopaedic and dental devices. In: R. Pignatello ed. Chapter 15 in Biomaterials Applications for Nanomedicine. InTech;2011;299-308. Available from:

http://www.intechopen.com/books/biomaterials-applications-for-nanomedicine/alumina-andzirconia-ceramicfor-orthopaedic-and-dental-devices

[136] Piconi C., Porporati, A.A. Bioinert ceramics: zirconia and alumina. (2016) In: Antoniac I. (eds) Handbook of Bioceramics and Biocomposites. Springer, Cham, pp 59-89, DOI: 10.1007/978-3-31912460-5_3.

[137] Chevalier J., Gremillard L. Ceramics for medical applications : A picture for the next 20 years. J. Eur. Ceram. Soc. 2009;29:1245-1255.

[138] Bohner M. Calcium from ceramics orthophosphates to calcium phosphate in medicine: cements. Injury Int. J. Care Injured 2000;31:S-D37-47.

[139] Rey C. Calcium phosphate biomaterials and bone mineral: Differences in composition, structure and properties. Biomaterials 1990;11:13-15.

[140] van Blitterswijk C.A., Hesseling S.C., Grote J.J., et al. The biocompatibility of hydroxyapatite ceramic: A study of retrieved human middle ear implants. J. Biomed. Mater. Res. 1990;94:433-453. [141] De Lange G.L., De Putter C., De Groot H. Histology of the attachment of gingival fibres to dental root implants of hydroxyapatite. Biomater. Biochem.1983;5:452-462.

[142] Martz E.O., Goel V.K, Pope M.H., et al. Materials and design of spinal implants - a review. J. Biomed. Mater. Res.1997;38:267-288. 
[143] Chetty A., Wepener I., Marei M.K. et al. Synthesis, Properties, and Applications of Hydroxyapatite. In: V.S. Gshalaev and A.C. Demirchan, eds. Chapter 2 in Hydroxyapatite: Synthesis, Properties and Applications. Nova Science Publishers;2012:91:13-20.

[144] LeGeros R.Z. Biodegradation and bioresorption of calcium phosphate ceramics. Clin. Mater. 1993;14:65-88.

[145] Daculsi G., Laboux O., Malard O. et al. Current state of the art of biphasic calcium phosphate bioceramics. J. Mater. Sci. Mater. Med. 2003;14:195-200.

[146] Bouler J.M., LeGeros R.Z., Daculsi G. Biphasic calcium phosphates: influence of three synthesis parameters on the HA/ $\beta$-TCP ratio. J. Biomed. Mater. Res. 2000;51:680-684.

[147] Brown O., McAfee M., Clarke S., et al. Sintering of biphasic calcium phosphate. J. Mater. Sci. Mater. Med. 2010;21: 2271-2279.

[148] Ishikawa K., Ducheyne P., Radin S. Determination of the $\mathrm{Ca} / \mathrm{P}$ ratio in calcium-deficient hydroxyapatite using X-ray diffraction analysis. J. Mater. Sci. Mater. Med. 1993;4:165-168.

[149] LeGeros R.Z., Lin S., Rohanizadeh R., et al. Biphasic calcium phosphate bioceramics: preparation, properties and applications. J. Mater. Sci. Mater. Med. 2003;14:201-209.

[150] Suchanek W., Yashima M, Kakihana M, Yoshimura M. Processing and mechanical properties of hydroxyapatite reinforced with hydroxyapatite whiskers. Biomaterials 1996;17:1715-1723.

[151] Hervas I., Montagne A., VanGorp A. et al. Fracture toughness of glasses and hydroxyapatite: A comparative study of 7 methods by using Vickers indenter. Ceram. Int. 2016:42:12740-12750.

[152] Šupová M. Substituted hydroxyapatites for biomedical applications: a review. Ceram. Int. 2015;41:9203-9231.

[153] Madupalli H., Pavan B., Tecklenburg M.M.J. Carbonate substitution in the mineral component of bone: Discriminating the structural changes, simultaneously imposed by carbonate in A and B sites of apatite. J. Sol. State Chem. 2017;255:27-35.

[154] LeGeros R.Z., Trautz O.R., LeGeros J.P., et al. Apatite crystallites: effects of carbonate on morphology. Science 1967;17:1409-1411.

[155] Bel Hadj Yahia F., Jemal M. Synthesis, structural analysis and thermochemistry of B-type carbonate apatites. Thermochimica Acta 2010;505:22-32.

[156] Fleet M.E., Liu X. Local structure of channel ions in carbonate apatite. Biomaterials 2005;26:7548-7554.

[157] Gibson I.R., Bonfield W. Novel synthesis and characterization of an AB-type carbonatesubstituted hydroxyapatite. J. Biomed. Mater. Res. 2002;59:697-708. 
[158] Frank-Kamenetskaya O., Kol'tsov A., Kuz'mina M., et al. Ion substitutions and nonstoichiometry of carbonated apatite- $(\mathrm{CaOH})$ synthesised by precipitation and hydrothermal methods. J. Mol. Struc. 2011;992:9-18.

[159] Phan Minh D., Dung Tran N., Nzihou A., et al. Carbonate-containing apatite (CAP) synthesis under moderate conditions starting from calcium carbonate and orthophosphoric acid. Mater. Sci. Eng. C 2013;33:2971-2980.

[160] Hench L.L., Splinter RJ, Allen WC, et al. Bonding mechanisms at the interface of ceramic prosthetic materials. J. Biomed. Mater. Res. 1971;2:117-141.

[161] Hench L.L. Bioceramics. J. Am. Ceram. Soc. 1998;81:1705-1728.

[162] Jones J.R. Review of bioactive glass: From Hench to hybrids. Acta Biomaterialia 2013;9:44574486.

[163] Huang W., Day D.E., Kittiratanapiboon K. et al. Kinetics and mechanisms of the conversion of silicate (45S5), borate, and borosilicate glasses. J. Mater. Sci. Mater. Med. 2006; 17:583-596.

[164] Yao A., Wang D., Huang W. et al. In vitro bioactive characteristics of borate-based glasses with controllable degradation behaviour. J. Am. Ceram. Soc., 2007;90:303-306.

[165] Kokubo T. Bioactive glass-ceramics - properties and applications. Biomaterials 1991;12:155156.

[166] Carrodeguas R.G., De Aza S. $\alpha$-Tricalcium phosphate: synthesis, properties and biomedical applications. Acta Biomater. 2011;7:3536-3546.

[167] Marković S., Lukić M.J., Škapin S.D. et al. Designing, fabrication and characterization of nanostructured functionally graded HA/BCP ceramics. Ceram. Int. 2015;41:2654-2667.

[168] Jaffe W.L., Scott D.F. Current concepts review - Total hip arthroplasty with hydroxyapatitecoated prostheses, J. Bone Joint Surg. 1996;78:1918-1934.

[169] Soon G., Pingguan-Murphy B., Wee Lai K. et al. Review of zirconia-based bioceramic: surface modification and cellular response. Ceram. Int. 2016;42:12543-12555.

[170] Herman H. Plasma spray deposition processes. MRS Bull. 1988;13:60-67.

[171] Yang Y., Kim K.H., Ong J.L. A review on calcium phosphate coatings produced using a sputtering process - an alternative to plasma spraying, Biomaterials 2005;26:327-337.

[172] Pardun K., Treccani L., Volkmann E. et al. Mixed zirconia calcium phosphate coatings for dental implants: Tailoring coating stability and bioactivity potential. Mater. Sci. Eng. C. Mater. Biol. Appl. 2015;48:337-346.

[173] Kim H.W., Noh Y.J., Koh Y.H., et al. Effect of $\mathrm{CaF}_{2}$ on densification and properties of hydroxyapatite-zirconia composites for biomedical applications. Biomaterials 2002;23:4113-4121. 
[174] Juang H.Y., Hon M.H. Fabrication and mechanical properties of hydroxyapatite-alumina composites. Mater. Sci. Eng. C 1994;2:77-81.

[175] Shahabudin N.S., Ahmad Z.A., Abdullah N.A. Alumina foam (AF) fabrication optimization and SBF immersion studies for AF, hydroxyapatite (HA) coated AF (HACAF) and HA-bentonite coated AF (HABCAF) bone tissue scaffolds. Procedia Chem. 2016;19:884-890.

[176] Ban S., Hasegawa J., Maruno S. Fabrication and properties of functionally gradient bioactive composites comprising hydroxyapatite containing glass coated titanium. Mater. Sci. Forum 1999;308-311:350-355.

[177] Jitcharoen J., Padture N.P., Giannakopoulos A.E. et al. Hertzian-Crack Suppression in Ceramics with Elastic-Modulus-Graded Surfaces. J. Am. Ceram. Soc. 1998;1:2301-2308.

[178] Fabris D., Souz J.C.M., Silva F.S. et al. Thermal residual stresses in bilayered, trilayered and graded dental ceramics. Ceram. Int. 2017;43:3670-3678.

[179] Burke F.J., Fleming G.J., Nathanson D., et al. Are adhesive technologies needed to support ceramics? An assessment of the current evidence. J. Adhes. Dent. 2002;4:7-22.

[180] Marshall S.J., Balooch M., Habelitz S. et al. The dentine-enamel junction-a natural, multilevel interface. J. Eur. Ceram. Soc. 2003;23:2897-2904.

[181] Cui C, Sun J. Optimizing the design of bio-inspired functionally graded material (FGM) layer in all-ceramic dental restorations. Dent. Mater. J. 2014;33:173-178.

[182] Nukavarapu S.P., Dorcemus D.L. Osteochondral tissue engineering: Current strategies and challenges. Biotechnol. Adv. 2013;31:706-721.

[183] Jiang J., Tang A., Ateshian G.A. et al. Bioactive stratified polymer ceramic-hydrogel scaffold for integrative osteochondral repair. Ann. Biomed. Eng. 2010;38:2183-2196.

[184] Liao S., Wang W., Uo M. et al. A three-layered nano-carbonated hydroxyapatite/collagen/PLGA composite membrane for guided tissue regeneration. Biomaterials 2005;36:7564-7571.

[185] Wang Q., Wang Q., Wan C. Preparation and evaluation of a biomimetic scaffold with porosity gradients in vitro. Anais da Academia Brasileira de Ciências 2012;84:9-16.

[186] Miao X., Sun D. Graded/gradient porous biomaterials. Materials 2010;3:26-47.

[187] Petit C., Palmero P., Tulliani J.M. Private communication.

[188] Beekmans H.C.S., Meijer G.J., Barkhuysen R. et al. The hydroxylapatite-bone interface: 10 years after implant installation. Int. J. Oral Maxillofac. Surg. 2008;37:768-772.

[189] Lu J., Descamps M., Dejou J. et al. The biodegradation mechanism of calcium phosphate biomaterials in bone, J. Biomed. Mater. Res. Appl. Biomater. 2002;63:408-412.

[190] Dorozhkin S.V. Calcium orthophosphate-based bioceramics. Materials 2013;6:3840-3942. 
[191] Lombardi M., Palmero P., Haberko K. et al. Processing of a natural hydroxyapatite powder: From powder optimization to porous bodies development. J. Eur. Ceram. Soc. 2011;31:2513:2518. [192] Marcassoli P., Cabrini M., Tirillò J. et al. Mechanical characterization of hydroxyapatite micro/macro-porous ceramics obtained by means of innovative gel-casting process. Key Eng. Mater. 2010;417-418:565-568.

[193] Tulliani J.M., Lombardi M., Palmero P. et al. Development and mechanical characterization of novel ceramic foams fabricated by gel-casting. J. Eur. Ceram. Soc. 2013;33:1567-1576.

[194] Werner J., Linner-Krčmar B., Friess W., et al. Mechanical properties and in vitro cell compatibility of hydroxyapatite ceramics with graded pore structure. Biomaterials 2002;23:42854294.

[195] Kalita S.J., Bose S., Hosick H.L. et al. Development of controlled porosity polymer-ceramic composite scaffolds via fused deposition modelling. Mater. Sci. Eng. C 2003;23:611-620.

[196] Tan K.H., Chua C.K., Leong K.F. et al. Fabrication and characterization of three-dimensional poly(ether-ether-ketone)/-hydroxyapatite biocomposite scaffolds using laser sintering. Proceedings of the Institution of Mechanical Engineers, Part H. Journal of Engineering in Medicine 2005;219:183194.

[197] Bian W., Li D., Lian Q., et al. Fabrication of a bio-inspired beta-tricalcium phosphate/collagen scaffold based on ceramic stereolithography and gel-casting for osteochondral tissue engineering. Rapid Prototyping Journal 2012;18:68-80.

[198] Bose S., Dasgupta S., Tarafder S. et al. Microwave-processed nanocrystalline hydroxyapatite: Simultaneous enhancement of mechanical and biological properties. Acta Biomaterialia 2010;6:3782-3790.

[199] Palmero P. Structural ceramic nanocomposites: A review of properties and powders' synthesis methods. Nanomaterials 2015;52:656:696.

[200] Balasundaram G., Sato M., Webster T.J. Using hydroxyapatite nanoparticles and decreased crystallinity to promote osteoblast adhesion similar to functionalizing with RGD. Biomaterials 2006;27:2798-2805.

[201] Choi S.W., Zhang Y., Thomopoulos S. et al. In vitro mineralization by preosteoblasts in poly(DL-lactide-co-glycolide) inverse opal scaffolds reinforced with hydroxyapatite nanoparticles. Langmuir 2010;26:12126-12131.

[202] Chen I.W., Wang X.H. Sintering dense nanocrystalline ceramics without final-stage grain growth. Nature 2000;404:168-171.

[203] Zhao S., Xiao W., Rahaman M.N. et al. Robocasting of silicon nitride with controllable shape and architecture for biomedical applications. Int. J. App. Ceram. Tech. 2016;13:117-127. 
[204] Belmonte M., Gonzalez-Julian J., Miranzo P. et al. Continuous in situ functionally graded silicon nitride materials. Acta Materialia 2009;57:2607-2612.

[205] Petzow G., Herrmann M. Silicone nitride ceramics. In High Performance Non-Oxide Ceramics II. Springer: 2002;102:47-167.

[206] Dressler W., Kleebe H.J., Hoffman M.J. et al. Model experiments concerning abnormal grain growth in silicon nitride. J. Eur. Ceram. Soc. 1996, 16, 3-14.

[207] Imamura H., Hirao K., Brito M.E., et al. Further improvement in mechanical properties of highly unisotropic silicon nitride ceramics. J. Am. Ceram. Soc. 2000;83:495-500.

[208] Le Ferrand H., Bouville F., Niebel T.P. et al. Magnetically assisted slip casting of bioinspired heterogeneous composites. Nat. Mater. 2015;14:1172-1180.

[209] Erb R.M., Libanori R., Rothfuchs N., et al. Composites reinforced in three dimensions by using low magnetic fields. Science 2012;335:1994.

\section{List of Table and Figure captions}

Table 1: Overview of developed FGCs: application fields and investigated compositions.

Table 2: Physical and mechanical properties of bone and teeth tissues. $\mathrm{L}=$ longitudinal loading direction, $\mathrm{T}=$ transversal loading direction [58,70,73-76,78,80-85].

Table 3: Examples of FGCs developed in the biomedical field and their specific applications

Table 4: The preferred scaffold pore size for different cell types, adapted from [86] with the permission of Elsevier under the licence $n^{\circ} 4206870438536$.

Figure 1: (A) Schematic section of the bone, showing its hierarchical and multi-layered structure, with different porosity levels in osteonal cortical bone. Reprinted from [72] with the permission of Elsevier under the licence $n^{\circ}$ 4206351457998; (B) Microstructure of natural tooth, showing the morphology of dentin, enamel and enamel-dentin junction (DEJ). Reprinted from [84] with the permission of Elsevier under the licence $\mathrm{n}^{\circ} 4206360555100$.

Figure 2: Graded monolithic glass-zirconia four-unit frameworks and single crowns with white (top) and light yellow (centre) shades. Similar framework and crown made from monolithic zirconia (bottom). Reprinted from [132] with the permission of Elsevier under the licence $n^{\circ} 4206990104304$.

Figure 3: (A) Optical; (B) micro-CT; and (C,D) SEM images of two-layer HA scaffold with a dense internal core and porous outer layer. Reprinted from [46] under the Creative Commons Attribution (CC BY) license.

Figure 4: Design and digital photo of the three-layer sample (A); FESEM image of the microstructure of the ceramic core (B) and of the PCL/BTC our layer (C); stereomicroscope image highlighting the interface between the dense core and the porous ceramic layer. Unpublished results [187]. 
Figure 5: Design and fabrication of a tooth-like structure through magnetically assisted slip casting. a) schematic representation of the target complex-shaped part, comprising a two-layer with locally distinct platelet orientation and chemical composition; b) synthetic tooth-like part, showing crosssectional cut to reveal its internal two-layer structure; c) elemental analysis of a part of the two-layer (box d in c); d) SEM image of the synthetic DEJ, highlighting the distinct platelet orientation in each of the two adjacent layers. Adapted from [208] with the permission of Nature Publishing Group under the licence $\mathrm{n}^{\circ} 4207791408472$. 


\section{Tables}

Table 1

\begin{tabular}{|c|c|c|c|}
\hline Field of Application & Examples of components & Examples of investigated compositions & References \\
\hline Aerospace/Automotive & $\begin{array}{l}\text { Thermal barrier coatings } \\
\text { (TBCs) and environmental } \\
\text { barrier coatings (EBCs) for } \\
\text { gas turbine engines, used in } \\
\text { automobiles, helicopter, aero } \\
\text { and marine vehicles; } \\
\text { protective layers for } \\
\text { combustion chambers, rocket } \\
\text { heat shields; disk brake rotor } \\
\text { systems for automotive }\end{array}$ & $\begin{array}{l}\mathrm{Al}_{2} \mathrm{O}_{3} / \mathrm{LaAl}_{12} \mathrm{O}_{19} \text { (lanthanum hexa-aluminate) } \\
\mathrm{YSZ} / \mathrm{Gd}_{2} \mathrm{Zr}_{2} \mathrm{O}_{7} \\
\mathrm{Gd}_{2} \mathrm{Zr}_{2} \mathrm{O}_{7} /(\mathrm{Ce}, \mathrm{Y}) \text {-stabilized } \mathrm{ZrO}_{2} \\
\mathrm{La}_{2} \mathrm{Zr}_{2} \mathrm{O}_{7} / 8 \mathrm{YSZ} \\
\mathrm{LaMgAl}_{11} \mathrm{O}_{19} / \mathrm{YSZ} \\
\mathrm{La}_{2}\left(\mathrm{Zr}_{0.7} \mathrm{Ce}_{0.3}\right)_{2} \mathrm{O}_{7} / 8 \mathrm{YSZ} \\
\mathrm{Al}_{2} \mathrm{O}_{3}-\mathrm{Al}_{2} \mathrm{TiO}_{5}\end{array}$ & $\begin{array}{l}{[9]} \\
{[10]} \\
{[11]} \\
{[12]} \\
{[13]} \\
{[14]} \\
{[15]} \\
{[16]} \\
{[17]} \\
{[18][19]} \\
{[20]} \\
{[21]}\end{array}$ \\
\hline Military & $\begin{array}{l}\text { Lightweight army systems, } \\
\text { ultralight weapons, } \\
\text { lightweight military } \\
\text { equipment, armoured vehicles, } \\
\text { bulletproof vests }\end{array}$ & $\begin{array}{l}\text { SiC fibers/Nasicon; Mullite fibers/Nasicon } \\
\mathrm{Al}_{2} \mathrm{O}_{3} / \mathrm{ZrO}_{2} \\
\mathrm{ZrO}-\mathrm{Zr}_{2} \mathrm{CN} / \mathrm{Si}_{3} \mathrm{~N}_{4}\end{array}$ & $\begin{array}{l}{[22]} \\
{[23]} \\
{[24]}\end{array}$ \\
\hline Machining & $\begin{array}{l}\text { Cutting tools, wear resistant } \\
\text { linings and parts }\end{array}$ & $\begin{array}{l}\mathrm{Al}_{2} \mathrm{O}_{3} / \mathrm{TiC} ; \mathrm{Al}_{2} \mathrm{O}_{3} /(\mathrm{W}-\mathrm{Ti}) \mathrm{C} \\
\mathrm{TiC}-\mathrm{TiN} \\
\text { WC/Co and multiple coated WC/Co; WC:Ti(C,N) } \\
\mathrm{SiAlON}-\mathrm{Si}_{3} \mathrm{~N}_{4}\end{array}$ & $\begin{array}{l}{[25]} \\
{[26]} \\
{[27]} \\
{[28]} \\
{[29]} \\
{[30]}\end{array}$ \\
\hline Refractories & $\begin{array}{l}\text { Glass-melting furnaces, } \\
\text { feeders, forehearth, tubes, } \\
\text { plungers, mantle blocks, } \\
\text { orifice rings }\end{array}$ & $\begin{array}{l}\mathrm{ZrO}_{2}-\mathrm{Al}_{2} \mathrm{O}_{3} / \mathrm{Mullite} \\
\mathrm{SiAlON}, \mathrm{SiAlON}-\mathrm{Si}_{3} \mathrm{~N}_{4} \\
\text { Mullite } / \mathrm{Al}_{2} \mathrm{O}_{3}\end{array}$ & $\begin{array}{l}{[31]} \\
{[30]} \\
{[32]} \\
{[33]} \\
{[34]}\end{array}$ \\
\hline Energy & $\begin{array}{l}\text { Turbine blades, evaporator } \\
\text { tubes in gas turbine } \\
\text { combustors, components for } \\
\text { thermionic/thermoelectric } \\
\text { system, piezoelectric } \\
\text { materials, cathode materials } \\
\text { for solid oxide fuel cells }\end{array}$ & $\begin{array}{l}\mathrm{Ti}_{48} \mathrm{Al}_{2} \mathrm{Cr}_{2} \mathrm{Nb} / \mathrm{Ti}_{46} \mathrm{Al}_{3} \mathrm{Cr}_{5} \mathrm{Nb}_{2} \mathrm{Ta} \\
\mathrm{ZnO} \\
\mathrm{B}_{2} \mathrm{Te}_{3}, \mathrm{Sb}_{2} \mathrm{Te}_{3}, \mathrm{PbTe}-\text { based FGMs } \\
\mathrm{Pb}\left[\mathrm{Ti}_{\mathrm{x}} \mathrm{Zr}_{1-\mathrm{x}}\right] \mathrm{O}_{3}(\mathrm{PZT}), \mathrm{PZT}-\mathrm{PVDF} \\
\mathrm{SiC} \\
\mathrm{La}_{\mathrm{x}} \mathrm{Sr}_{1-\mathrm{x}} \mathrm{Co}_{\mathrm{y}} \mathrm{Fe}_{1-\mathrm{y}} \mathrm{O}_{3-\delta}(\mathrm{LSCF}) \\
(1-\mathrm{x}) \mathrm{Pb}\left(\mathrm{Ni}_{1 / 3} \mathrm{Nb}_{2 / 3}\right) \mathrm{O}_{3-\mathrm{x}} \mathrm{Pb}\left(\mathrm{Zr}_{0.3} \mathrm{Ti}_{0.7}\right) \mathrm{O}_{3} \\
\left.(\mathrm{La}, \mathrm{Sr}) \mathrm{MnO}_{3}-(\mathrm{La}, \mathrm{Sr})(\mathrm{Co}, \mathrm{Fe}) \mathrm{O}_{3}\right]-(\mathrm{Ga}-\text { doped } \\
\left.\mathrm{CeO}_{2}\right)\end{array}$ & $\begin{array}{l}{[35]} \\
{[36]} \\
{[37]} \\
{[38]} \\
{[39]} \\
{[40]} \\
{[41]} \\
{[42]} \\
{[43]}\end{array}$ \\
\hline $\begin{array}{l}\text { Electronic/ } \\
\text { Optoelectronic }\end{array}$ & $\begin{array}{l}\text { Semi-conductor devices, anti- } \\
\text { reflective layers, sensors, } \\
\text { fibres, graded index lenses, } \\
\text { piezoelectric ceramics } \\
\text { photodetectors for solar cells }\end{array}$ & $\begin{array}{l}\mathrm{AlN} / \mathrm{GaN} \\
\mathrm{Pb}\left(\mathrm{Ni}_{1 / 3} \mathrm{Nb}_{2 / 3}\right) \mathrm{O}_{3}-\mathrm{PbZrO}_{3}-\mathrm{PbTiO}_{3} \\
\mathrm{PZT} \\
\text { PZT-PVDF }\end{array}$ & $\begin{array}{l}{[44]} \\
{[42]} \\
{[38]} \\
{[39]}\end{array}$ \\
\hline Biomedical & $\begin{array}{l}\text { Graded hip prostheses and } \\
\text { implants, calcium-phosphates- } \\
\text { based porosity graded } \\
\text { scaffolds, graded coatings, }\end{array}$ & $\begin{array}{l}\mathrm{Ca}_{5}\left(\mathrm{PO}_{4}\right)_{3}(\mathrm{OH})(\mathrm{HA}) \\
\mathrm{Al}_{2} \mathrm{O}_{3} \\
\mathrm{Al}_{2} \mathrm{O}_{3} / \mathrm{ZrO}_{2}\end{array}$ & $\begin{array}{l}{[45]} \\
{[46]} \\
{[47]} \\
{[48]}\end{array}$ \\
\hline
\end{tabular}


interfaces for bone fixation, nature-inspired tissue

engineered scaffolds, dental

implants and dental

restorations, drug delivery

systems
[49]

[50]

[51]

[52]

[53]

[54]

[55]

[56]

Table 2

\begin{tabular}{ccccc}
\hline & $\begin{array}{c}\text { Young's modulus } \\
(\mathbf{G P a})\end{array}$ & $\begin{array}{c}\text { Tensile strength } \\
(\mathbf{M P a})\end{array}$ & $\begin{array}{c}\text { Compressive strength } \\
(\mathbf{M P a})\end{array}$ & $\begin{array}{c}\text { Fracture toughness } \\
(\mathbf{M P a} \sqrt{\mathbf{m})}\end{array}$ \\
\hline Cortical bone (L) & 17 & $80-151$ & $170-193$ & $2-12$ \\
Cortical bone (T) & $6-13$ & $51-56$ & 133 & $2-12$ \\
Cancellous bone & $0.1-5$ & 10 & $7-10$ & 0.1 \\
Enamel & $60-100$ & $11.5-42.2$ & $\sim 62$ & $0.7-4$ \\
Dentin & $13-45$ & $48.7-61.6$ & $\sim 194$ & $1-2$ \\
\hline
\end{tabular}


Table 3

\begin{tabular}{l} 
FGC structures \\
\hline Compositionally graded $\mathrm{Al}_{2} \mathrm{O}_{3} / \mathrm{ZrO}_{2}$ \\
Porosity graded $\mathrm{Al}_{2} \mathrm{O}_{3}-\mathrm{ZrO}_{2}$ composite \\
Compositionally graded $\mathrm{Al}_{2} \mathrm{O}_{3}-\mathrm{ZrO}_{2}$ composite \\
/ bioglass \\
Compositionally graded $\mathrm{Al}_{2} \mathrm{O}_{3}$ or $\mathrm{ZrO}$ or \\
$\mathrm{Al}_{2} \mathrm{O}_{3}-\mathrm{ZrO}_{2}$ composite / $\mathrm{HA} \mathrm{or} \mathrm{bioglass}^{2}$
\end{tabular}

$\mathrm{Al}_{2} \mathrm{O}_{3}-\mathrm{ZrO}_{2}$ composite / HA or bioglass

Porosity graded HA or $\beta$-TCP

Compositionally graded HA / $\alpha$ - or $\beta$-TCP

Compositionally graded CaP-based coatings on $\mathrm{Al}_{2} \mathrm{O}_{3}$ or $\mathrm{ZrO}_{2}$ or $\mathrm{Al}_{2} \mathrm{O}_{3}-\mathrm{ZrO}_{2}$ composite substrates

Compositionally graded polymer (e.g. PCL, collagen, PLA) / CaP

Microstructurally graded HA

Microstructurally graded $\mathrm{Al}_{2} \mathrm{O}_{3}$ or $\mathrm{ZrO}_{2}$

Applications and benefits

Orthopaedic or dental implants with high

mechanical strength

[48]

[87]

[88]

Orthopaedic implants with mechanical strength and osteoconductivity

[89]

Dental implants with mechanical strength and

bioactivity / osteoconductivity

[90]

Orthopaedic implants with mechanical

strength and bioactivity / osteoconductivity

Bone substitutes mimicking the core-shell

[46] structure of bone (cortical / cancellous)

[97]

Bone substitute with drug delivery system

Cage for spinal fusion

[98]

[99]

Bone substitutes with a gradation of

[100] resorption and bioactivity

[101]

Orthopaedic or dental implants with a

resorbable and bioactive surface in contact with bone

[104]

[105]

[107]

[108]

inorganic composition of bone

Osteochondral (bone-cartilage) scaffold to repair articular cartilage and subchondral bone

111

Bone substitutes with graded grain size to obtain graded mechanical and biological properties

Orthopaedic implants with graded grain size to obtain graded mechanical properties

Table 4

\begin{tabular}{ccc}
\hline Tissue regeneration & Cell size $(\boldsymbol{\mu} \mathbf{m})$ & Preferred pore diameter $(\boldsymbol{\mu m})$ \\
\hline Vascular & $600[118-$ SAL02] & 5 (for neovascularisation) [121] \\
Hepatocytes & $20-40[119-$ GAL07] & $20[120]$ \\
Fibroblast & $20-50[118-$ SAL02] & $90-360[122]$ \\
Bone & $20-30[120-$ OOT06] & $100-350[123]$ \\
\hline
\end{tabular}




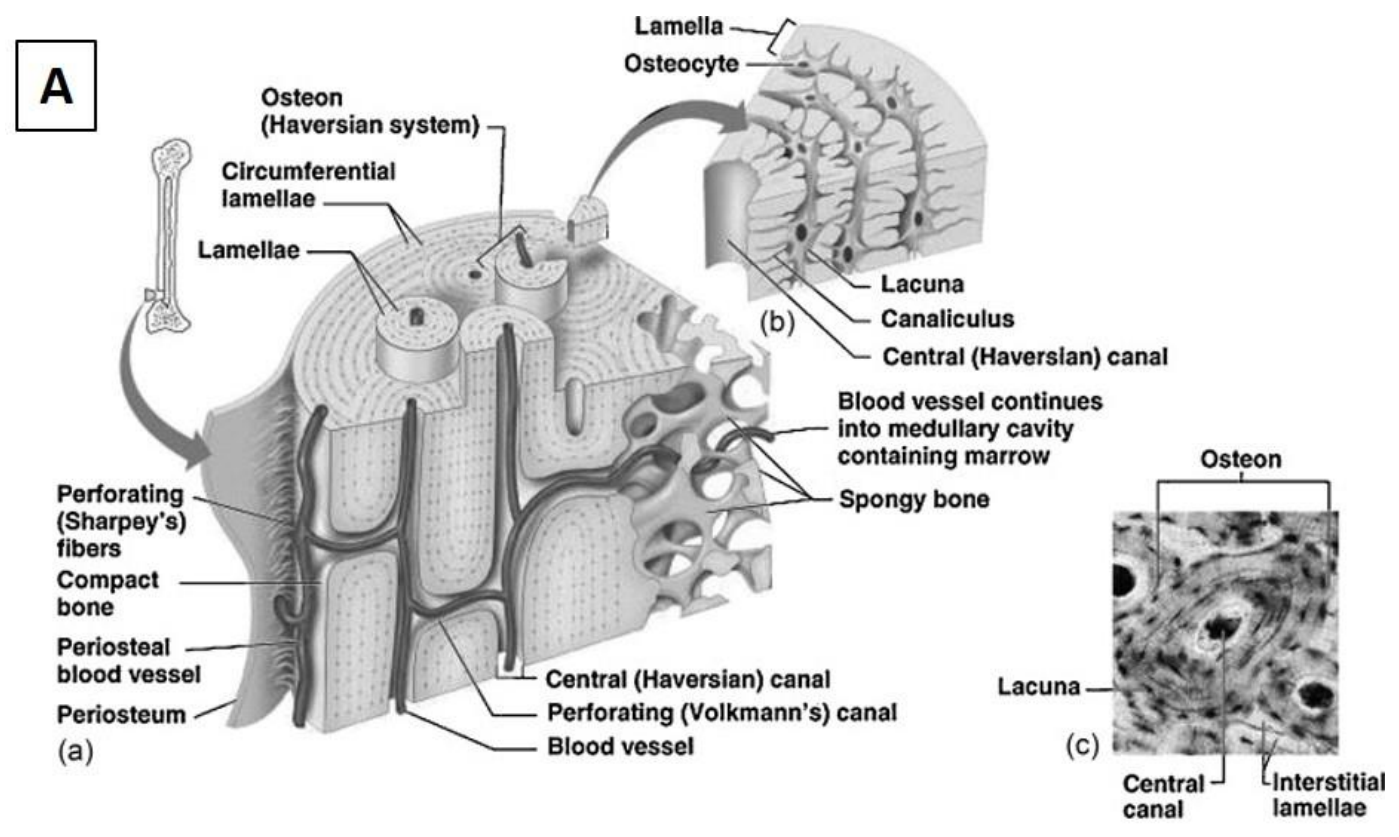

\section{B}
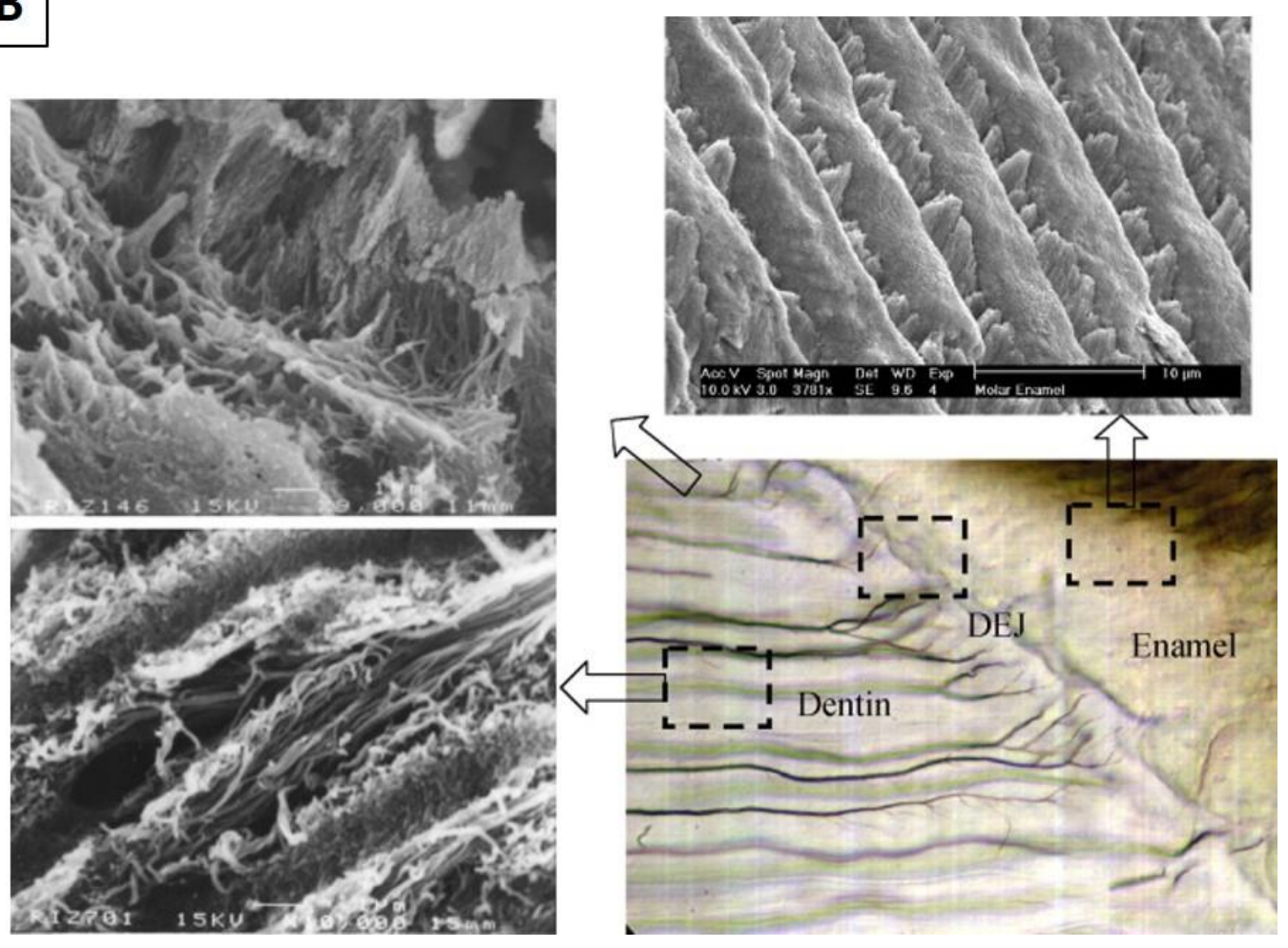

Figure 1 

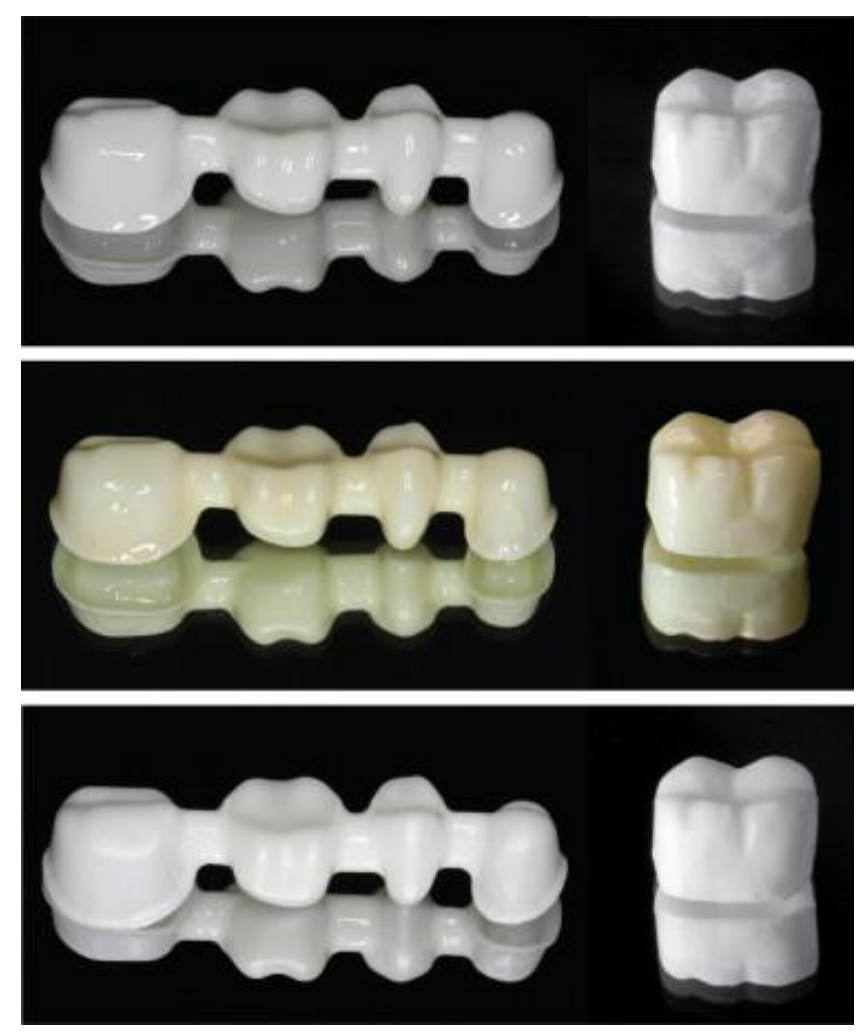

Figure 2
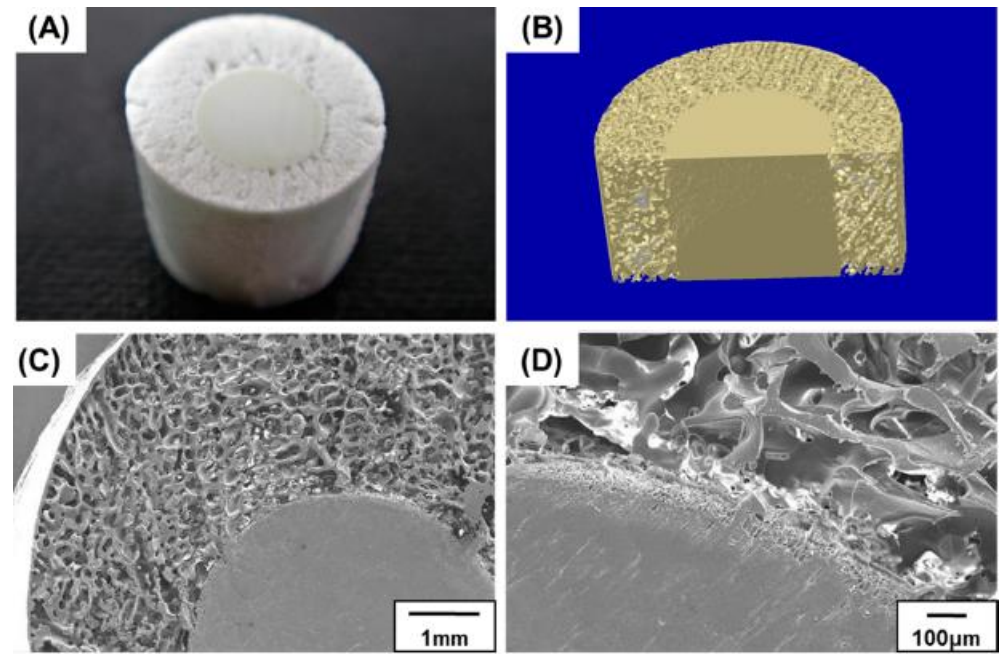

(D)
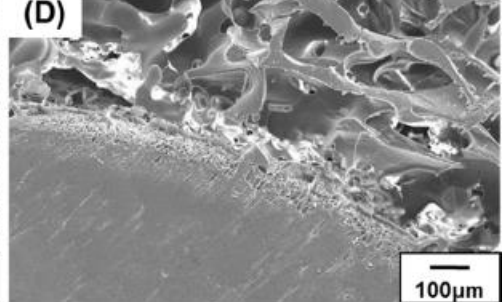

Figure 3 

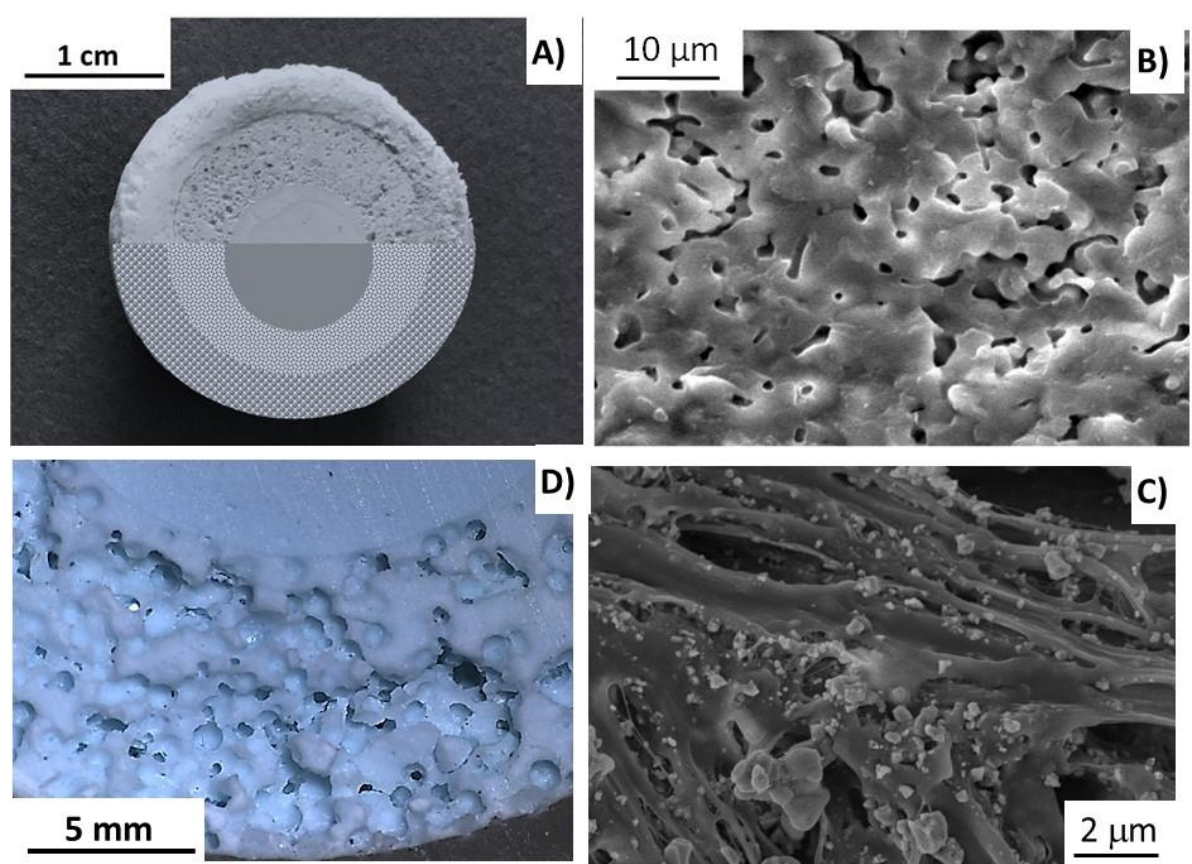

Figure 4
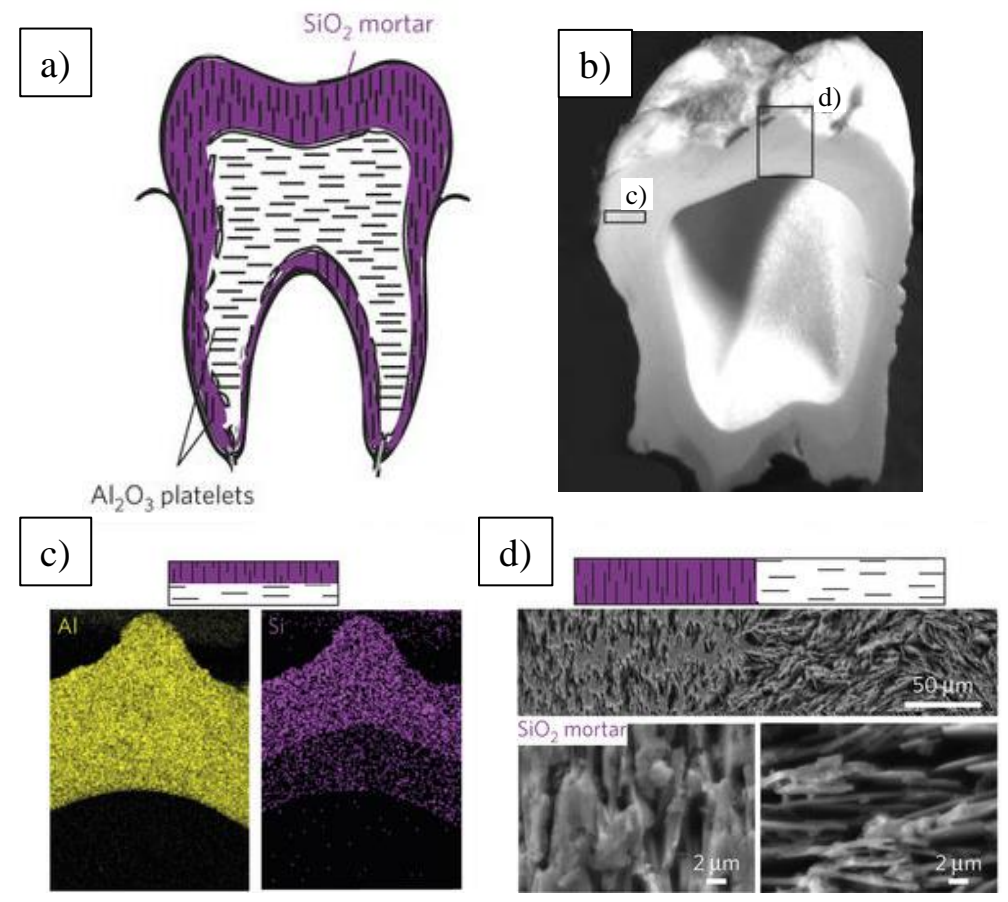

Figure 5 